\title{
Beef cattle production : costs and returns for the cow-calf system in West Virginia
}

Alfred L. Barr

Follow this and additional works at: https://researchrepository.wvu.edu/ wv_agricultural_and_forestry_experiment_station_bulletins

\section{Digital Commons Citation}

Barr, Alfred L., "Beef cattle production : costs and returns for the cow-calf system in West Virginia" (1966). West Virginia Agricultural and Forestry Experiment Station Bulletins. 527.

https://researchrepository.wvu.edu/wv_agricultural_and_forestry_experiment_station_bulletins/483 
West Virginia University Libraries 



\section{BULLETIN 527}

AG-ENI LIBRT 1966 AG-ENG LIBRARY WEST VIRGINIA UNIVERSITY
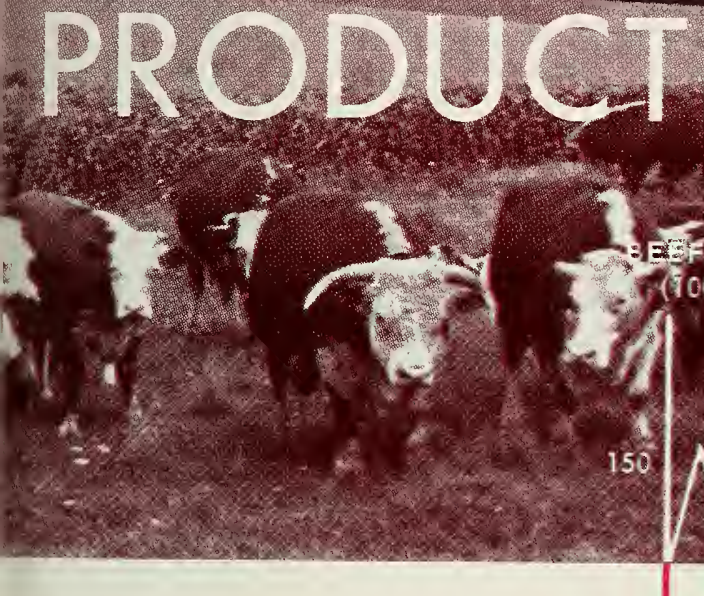

COSTS AND

RETURNS FOR

THE COW-CALF

SYSTEM IN

WEST VIRGINIA

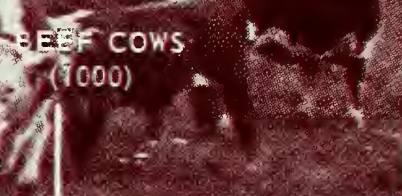

W. Vo. Number of Bear Caws
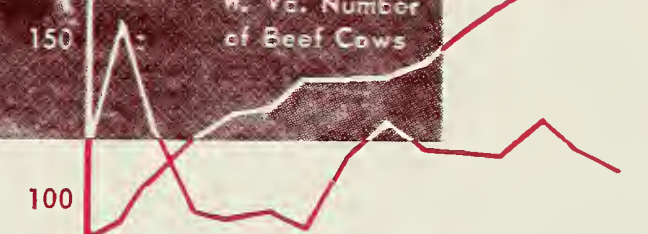

From Cattle and Calves

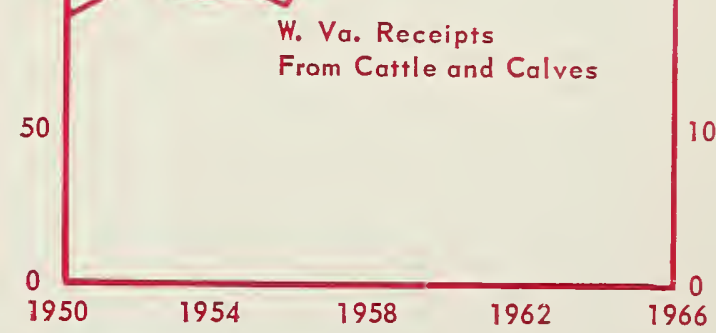

WEST VIRGINIA UNIVERSITY AGRICULTURAL EXPERIMENT STATION 


\section{THE AUTHOR}

The author of Beef Cattle Production: Costs and Returns for the Cow-Calf System in West Virginia is Alfred L. Barr, Associate Agricultural Economist in the West Virginia University Agricultural Experiment Station.

\section{ACKNOWLEDGMENTS}

The author wishes to acknowledge contributions of Mr. Joe Emch, Dr. Gerald Jung and Mr. George Toben to this publication. Mr. Emch provided the data and assisted with the estimates of the requirements and production for beef cattle. Dr. Jung provicled the requirement and yield estimates for the forage crops. Mr. Toben provided machinery cost data on which the various machinery cost estimates are based. All three individuals read the manuscript and made many valuable criticisms and suggestions.

West Virginia UNIVERSiTY Agricultural Experiment Station College of Agriculture and Forestry A. H. Vanlandingham, Diregtor MORGantown 


\section{Contents}

$$
\text { Page }
$$

INTRODUCTION $\ldots \ldots \ldots \ldots \ldots \ldots \ldots \ldots \ldots \ldots \ldots$

FORAGE REQUIREMENTS AND PRODUCTION ..... 4

Alfalfa-Orchardgrass Hay $\ldots \ldots \ldots \ldots \ldots \ldots \ldots \ldots$

Orghardgrass Hay $\ldots \ldots \ldots \ldots \ldots \ldots \ldots \ldots \ldots \ldots \ldots \ldots$

Clover-Timothy Hay $\ldots \ldots \ldots \ldots \ldots \ldots \ldots \ldots \ldots$

Corn Silage ......................... 8

CAPITAL REQUIREMENTS $\ldots \ldots \ldots \ldots \ldots \ldots \ldots \ldots, 9$

Maghinery Investient and Costs $\ldots \ldots \ldots \ldots \ldots \ldots .9$

Land Investment $\ldots \ldots \ldots \ldots \ldots \ldots \ldots \ldots \ldots \ldots \ldots \ldots \ldots$

Cropland Requirements ................ 14

Pasture Land Requirements .............. I5

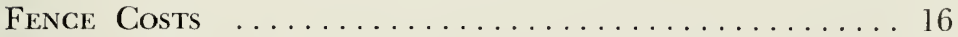

Building Investment $\ldots \ldots \ldots \ldots \ldots \ldots \ldots \ldots \ldots \ldots \ldots \ldots$

Bull Depreciation $\ldots \ldots \ldots \ldots \ldots \ldots \ldots \ldots \ldots \ldots \ldots$

GROSS INCOME $\ldots \ldots \ldots \ldots \ldots \ldots \ldots \ldots \ldots \ldots \ldots \ldots \ldots$ Is

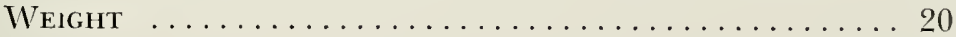

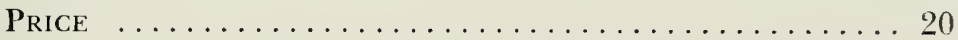

RETURNS TO OWNED FACTORS $\ldots \ldots \ldots \ldots \ldots \ldots 23$

SUMMARY AND CONCLUSIONS ............. 38 
Digitized by the Internet Archive in 2010 with funding from Lyrasis Members and Sloan Foundation 


\section{Beef Cattle Production: Costs and Returns for the Cow-Calf System in West Virginia ${ }^{1}$}

\section{Introduction}

ALFRED L. BARR

IN WEST VIRGINIA sales of forage-consuming livestock represent 1 about $1 / 2$ of the value of all farm products sold. Not only is livestock a major source of income to farmers of the State, but it is the major source of income in some counties.

The State's rough terrain makes much of the land unsuitable for agricultural uses other than for livestock production. The steepness of the terrain dictates that much of the land be used for permanent pasture with only the small valleys and gentle slopes available for row crop production and for meadows.

Forage is basic to livestock production. Pastures provicle forage for summer grazing, while meadows and corn are used to produce hay and silage for winter feed. Also, livestock provides the only available market for much of the pasture, hay, and silage produced within the State.

In recent years, the number of cattle kept for milk has declined from 322,000 in 1950 to 167,000 in 1965 . This decline leaves more forage (pasture, hay and silage) available for the other classes of grazing livestock, namely, beef and sheep. Although sheep have been one of the more profitable enterprises per animal unit, the number of sheep on farms has also been cleclining." Only the number of beef cattle, among the major classes of forage-utilizing livestock, has been increasing, with most of the increase being in the number of cows kept for the production of feeder calves (Table 1).

Many questions have been raised concerning the profitability of beef cattle production in West Virginia and the rate of return which can be realized from an investment of capital in the resources required for the production of feeder calves. Economic and technical changes

${ }^{1}$ Research reported herein was done under Hatch Project 165, Evaluation of Alternative Enterprises for West Virginia Farms.

${ }^{2}$ Barr, A. L., et al., Sheep Production-Costs and Returns in West Virginia. W. Va. Univ. Agr. Exp. Sta. Bull. 495, June, 1964. 
TABLE 1 *

Number of Forage-Consuming Livestock on West Virginia Farms, 1950,1960 , and 1965

\begin{tabular}{rrrrr}
\hline \hline & 1950 & 1960 & 1965 \\
\hline All Cattle $\ldots \ldots \ldots \ldots \ldots \ldots \ldots$ & 554,000 & 540,000 & 494,000 \\
Kept for Milk $\ldots \ldots \ldots \ldots \ldots$ & 322,000 & 212,000 & 167,000 \\
Beef Cows \& Heifers $\ldots \ldots \ldots$ & 119,000 & 188,000 & 205,000 \\
Beef Calves \& Steers $\ldots \ldots \ldots \ldots$ & 104,000 & 130,000 & 112,000 \\
Bulls $\ldots \ldots \ldots \ldots \ldots \ldots \ldots \ldots$ & 9,000 & 10,000 & 10,000 \\
Sheep $\ldots \ldots \ldots \ldots \ldots \ldots \ldots \ldots$ & 296,000 & 283,000 & 213,000 \\
\hline
\end{tabular}

* Source: West Virginia Agr. Stat.-W. Va. Crop Reporting Service, W. Va. Dept. of Agr. and Livestock and Poultry lnventory, January 1-U.S.D.A. Crop Reporting Board, Washington, D. C.

within agriculture also require that beef cattle producers continuously evaluate their production systems and methods and the size of business required to provide an adequate living.

This analysis was undertaken to provide such information to indivicluals concerned with beef cattle procluction. The basic data in this analysis are not necessarily representative of any individual production situation. The requirements, cost, and income estimates are designed to reflect typical expectations for long-run average prices, average or normal rainfall conditions and above average management. Either higher or lower prices, above or below average rainfall, or more or less efficient management would greatly alter the results for any given year or farm.

Estimates used are based on data obtained from experiments, farmer surveys, and estimates of specialists, scientists, and other experienced persons familiar with beef production in West Virginia. The present analysis is limited to the cow-calf program as other systems require more grain and are not generally as adaptable to West Virginia conditions.

\section{Forage Requirements and Production}

Forage production represents the largest single cost item in the production of feeder calves in West Virginia. Winter forage requirements for beef cattle exceed two tons of hay or hay equivalent of silage per cow plus replacements. Thus, a herd of 50 cows with replacements and bulls will require more than 100 tons of hay or hay equivalent of silage. This requirement can be met by using all hay or a combination of hay and silage. For small numbers of cows-50 or fewer head-the cost per ton of forage required of owning both hay and silage equipment is prohibitive. The farmer, from an economic standpoint, with the small number of cattle is likely to have only hay-making equipment, and should consider custom hiring the silo filled if silage is used. 
At the present time, the crops which are most likely to be used to meet the hay requirement are: (1) alfalfa-mixed hay, (2) orchardgrass hay, (3) clover-mixed hay, (4) small grain hay or (5) corn silage.

Partial budgets for establishment and harvest of each of these alternatives are presented in tables 2.1 through 2.8. In the budgets, expected yields are for high fertility levels and good management. These and higher yields have been attained consistently in experimental work.

\section{ALFALFA-ORCHARDGRASS HAY}

Alfalfa-orchardgrass hay is one of the most commonly found hay crops in West Virginia. It is grown on both bottomland and upland

\section{TABLE 2.1}

\section{Alfalfa-Orchardgrass Hay Seeded with Oats: Estimated Establishment Costs*}

\begin{tabular}{|c|c|c|c|c|c|c|}
\hline \multirow[b]{2}{*}{ Operation } & \multirow{2}{*}{ Equipment } & \multirow{2}{*}{$\begin{array}{l}\text { Times } \\
\text { Over }\end{array}$} & \multirow{2}{*}{$\begin{array}{c}\text { Labor } \\
\text { Hours/Acre }\end{array}$} & \multirow{2}{*}{$\begin{array}{c}\text { Tractor } \\
\text { Hours/Acre } \\
\end{array}$} & \multicolumn{2}{|c|}{ Equipment Cost } \\
\hline & & & & & Per Hour & Per Acre \\
\hline \multicolumn{7}{|c|}{ Machine and Labor Requirements Per Acre for Establishment: } \\
\hline Plow & 2-14" M.B. & 1.0 & 1.8 & 1.7 & $\$ .27$ & $\$ .46$ \\
\hline Disc & 8' Tandem & 2.0 & 1.0 & 1.0 & .19 & .19 \\
\hline $\begin{array}{l}\text { Drag } \\
\text { Fertilize }\end{array}$ & $10^{\prime}$ drag & 1.0 & .6 & .6 & .05 & .03 \\
\hline \& seed & $7^{\prime}$ drill & 1.0 & 1.0 & .7 & .50 & .35 \\
\hline (Sept.) & $7^{\prime}$ drill & 1.0 & 1.0 & .7 & .50 & .35 \\
\hline Total & & & 5.4 & 4.7 & & $\$ 1.38$ \\
\hline
\end{tabular}

Power and Machinery Costs for Establishment: Per Acre

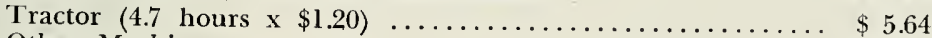

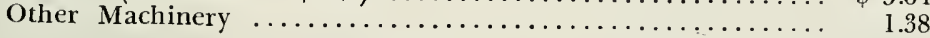

Total Power and Machinery $\ldots \ldots \ldots \ldots \ldots \ldots \ldots \ldots \ldots \$ \overline{7.02}$

Materials:

Fertilizer $(500 \#$ of $0-20-20$ at seeding \& $200 \# 0-18-36$ in Sept.) $\ldots \$ 22.50$

Seed (12\# Vernal Alfalfa@ $\$ .80$ \&.

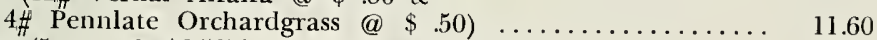

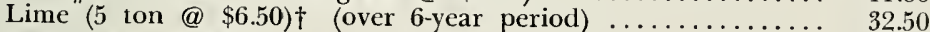

Oats (2 bu. @ \$2.00) .............................. 4.00

Total Materials Cost $\ldots \ldots \ldots \ldots \ldots \ldots \ldots \ldots \ldots \ldots \ldots, \$ 70.60$

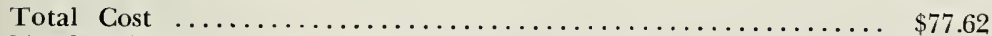

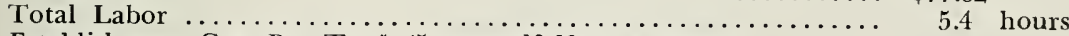

Establishment Cost Per Ton* ( 5 tons alfalfa x 5 years

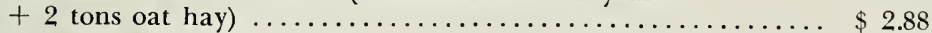

Labor Per Ton for Establishment $\ldots \ldots \ldots \ldots \ldots \ldots \ldots \ldots \ldots \ldots .21$ hours

*Excludes fixed costs of machinery and labor. Data derived from unpublished materials, Department of Agricultural Economics, West Virginia University and estimates from Department of Agronomy and Genetics, West Virginia University.

The price of lime varies greatly among counties, depending on distance from source. The 1961-63 average prlce paid by West Virginia farmers was $\$ 6.50$. The lime requirement will also vary greatly between areas of the State; an estimate of about one ton per acre per year is used for this analysis. 
soils. Requirements and costs of establishing alfalfa-orchardgrass hay and oats àre presented in Table 2.1. The power and machinery costs included in the budgets include variable costs only, that is, those costs which vary as acreage changes such as gasoline, lubrication, repair and maintenance. Depreciation, taxes, and interest on investment are not inclucled.

Materials listed are those required in the year of seeding except for lime which would be applied as needed in the year of establishment and when needed in subsequent years. To obtain an average yield of five tons per acre per year after the year of establishment and to retain a stand for five years requires good management and high levels of fertility. ${ }^{3}$

Oats are assumed to be planted with alfalfa as a companion crop. A yield of two tons of hay per acre is estimated for the oat crop. If oats are not seeded with the alfalfa, at least one cutting of alfalfa may be harvested during the year of establishment. Estimated costs of establishing an acre of alfalfa with oats seeded as a companion crop are $\$ 77.62$ plus labor. With a yield of two tons of oats and five tons of alfalfa for each of five years, establishment costs are $\$ 2.88$ per ton.

Harvest costs for the oat crop, which are presented in Table 2.2, are estimated at $\$ 3.37$ plus 2.38 hours of labor per ton. Annual maintenance and harvest costs for alfalfa are listed in Table 2.3. Weevil control and fertilization applications in addition to harvest costs will constitute the annual costs. Total annual costs are estimated to be $\$ 53.54$ per acre or $\$ 10.71$ per ton of hay plus 4.26 hours of labor. Annual and establishment costs total $\$ 13.59$ plus 4.47 hours of labor per ton.

\section{ORCHARDGRASS HAY}

The establishment costs for orchardgrass hay are presented in Table 2.4. Again, only variable machinery costs are included in the budgets.

Oats are assumed to be seeded with the orchardgrass as a companion crop at the time of establishment. Without a small grain crop, very little production would be obtained during the first year. Harvest costs and yield for the oat hay would be the same as when seeded with alfalfa (Table 2.2) .

Costs of establishing the orchardgrass and oats are estimated at $\$ 70.52$. The life of the orchardgrass stand is assumed to be ten years and an average annual yield of four tons is expected with the high

${ }^{3}$ Establishment costs are high for alfalfa; thus the stand must be retained and high yields obtained to keep establishment costs per ton down. Yields in excess of five tons per acre have been obtained consistently and stands have persisted in excess of six years in trials conducted by scientists of the West Virginia University Department of Agronomy and Genetics. 


\section{TABLE 2.2}

\section{Harvest Costs of Oat Hay (Seeded with Alfalfa, Clover, or Orchardgrass)*}

\begin{tabular}{|c|c|c|c|c|c|c|c|}
\hline \multirow{2}{*}{ Operation } & \multirow[b]{2}{*}{ Equipment } & \multirow{2}{*}{$\begin{array}{l}\text { Times } \\
\text { Over }\end{array}$} & \multirow{2}{*}{$\begin{array}{c}\text { Labor } \\
\text { Hours/Acre }\end{array}$} & \multirow{2}{*}{$\begin{array}{c}\text { Tractor } \\
\text { Hours/Acre }\end{array}$} & \multicolumn{3}{|c|}{ Equipment Cost } \\
\hline & & & & & Per Hou & & Per Acre \\
\hline \multicolumn{8}{|c|}{ Machine and Labor Requirements Per Acre: } \\
\hline Mow & $7^{\prime}$ mower & 1.0 & .5 & .5 & $\$ .65$ & & $\$ .33$ \\
\hline Rake & $12^{\prime}$ rake & 1.0 & .25 & .25 & .82 & & .41 \\
\hline Bale & Pickup baler & 1.0 & 1.0 & 1.0 & .75 & & .75 \\
\hline $\begin{array}{l}\text { Haul \& } \\
\text { store }\end{array}$ & Wagon & 1.0 & 3.0 & .6 & .05 & & .03 \\
\hline Total & & & 4.75 & 2.35 & & & $\$ 1.52$ \\
\hline \multicolumn{5}{|c|}{ Power and Machinery Costs: } & \multicolumn{3}{|c|}{ Per Acre } \\
\hline \multirow{2}{*}{\multicolumn{3}{|c|}{$\begin{array}{l}\text { Tractor }(2.35 \text { hours } \times \quad \$ 1.20) \\
\text { Other Machinery } \ldots \ldots \ldots \ldots\end{array}$}} & & & \multicolumn{3}{|c|}{$\$ 2.82$} \\
\hline & & Other Machinery $\ldots \ldots \ldots \ldots$ & & & \multicolumn{3}{|c|}{1.52} \\
\hline \multicolumn{3}{|c|}{ Total Power and Machinery } & & & \multicolumn{3}{|c|}{$\$ 4.34$} \\
\hline \multicolumn{8}{|c|}{ Materials: } \\
\hline \multicolumn{4}{|c|}{ Baler Twine $\left(\begin{array}{llll}\$ & .03 & \times & 80\end{array}\right)$} & & \multicolumn{3}{|c|}{$\$ 2.40$} \\
\hline \multirow{2}{*}{\multicolumn{4}{|c|}{ 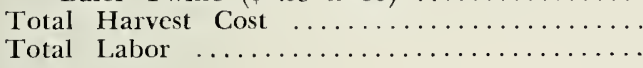 }} & & & \multicolumn{2}{|c|}{$\$ 6.74$} \\
\hline & & & & & $\ldots$. & 4.75 & hours \\
\hline \multicolumn{8}{|c|}{ Production: } \\
\hline \multirow{3}{*}{\multicolumn{5}{|c|}{$\begin{array}{l}\quad \text { Oat Hay } \ldots . . . . \\
\text { Harvest Cost Per Ton } \\
\text { Labor Per Ton ..... }\end{array}$}} & \multicolumn{3}{|c|}{2 tons } \\
\hline & & & & & & $\$ 3.37$ & \\
\hline & & & & & & 2.38 & hours \\
\hline
\end{tabular}

*Excludes fixed costs of machinery, land, and labor.

fertilization rates. Thus, establishment costs per ton are estimated at $\$ 1.86$ plus .15 hours labor.

Annual costs of harvest and fertilization are presented in Table 2.5. Total annual costs are estimated to be $\$ 57.39$ plus 22 hours of labor per acre. Annual costs per ton are $\$ 14.35$ plus 5.5 hours of labor if a yield of four tons per acre is realized. Total costs are $\$ 16.21$ plus 5.65 hours of labor per ton.

\section{CLOVER-TIMOTHY HAY}

Red clover and timothy constitute the most popular hay mixture grown in West Virginia with 351,000 acres produced in 1963. Costs of establishment of clover and timothy with oats as a companion crop are estimated in Table 2.6. Total costs of establishment are estimated at $\$ 54.72$ plus 5.4 hours of labor per acre or $\$ 6.84$ plus 0.7 hours of labor per ton. An annual yield of three tons per acre for the clover for two years after establishment and two tons of oat hay during the establishment year are assumed. 
TABLE 2.3

Alfalfa-Mixed Hay: Estimated Annual Costs*

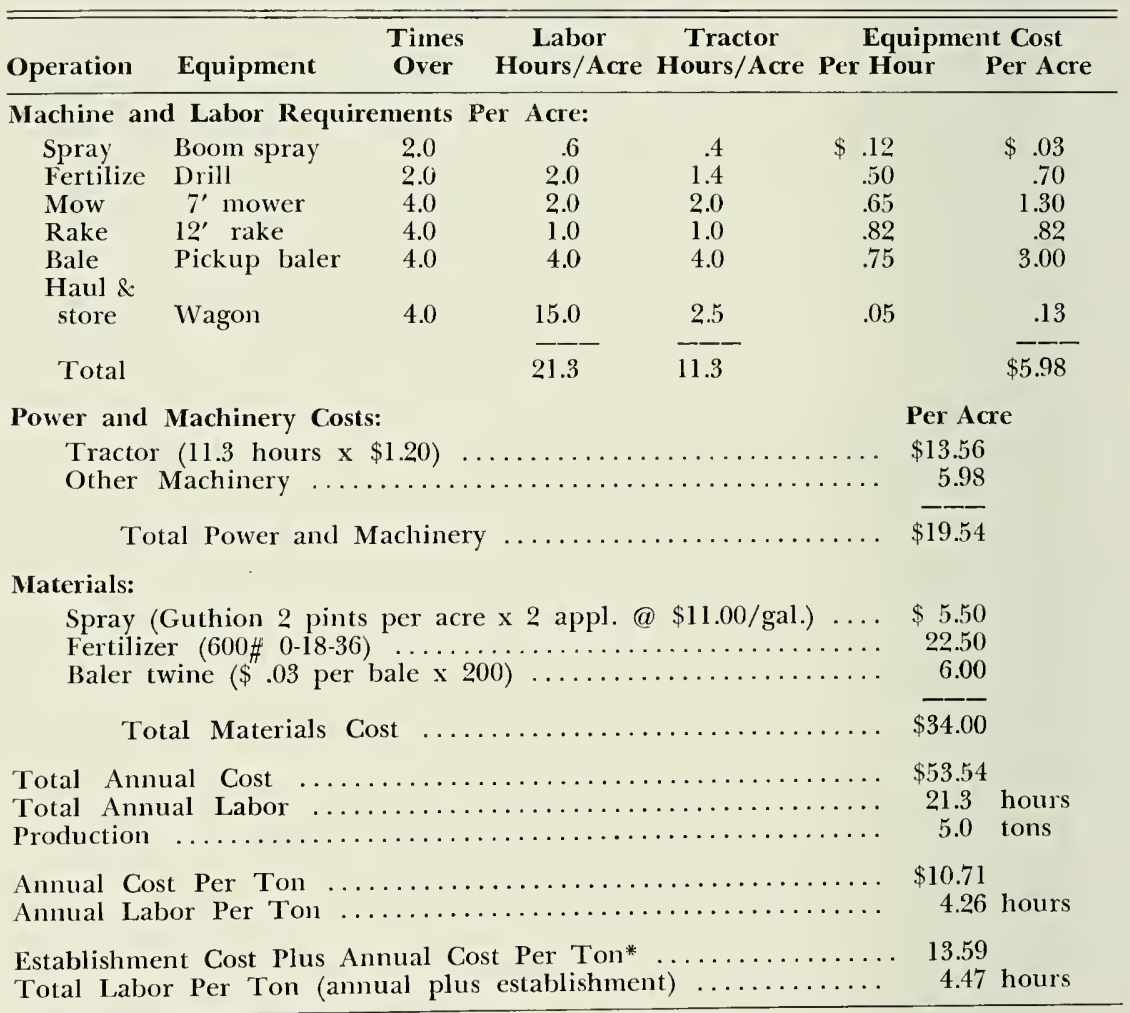

*Excludes fixed costs of machinery, land, and labor.

Harvest costs for the oat hay would be the same as those presented in Table 2.2. Annual costs for the clover-timothy hay are estimated in Table 2.7. Estimated annual and establishment costs are $\$ 16.32$ per ton plus 5.2 hours of labor.

\section{CORN SILAGE}

Corn silage is used as forage by beef producers throughout the State. In Table 2.8, the costs of producing an acre of corn silage are presented. The machinery costs include only the variable or operating costs. They do not include the fixed costs of machinery ownership. Silage yields are assumed to be 20 tons per acre. Total costs per acre are estimated to be $\$ 68.17$ plus 19.8 hours of labor; costs per ton of silage are $\$ 3.40$ plus 1 hour of labor. 
TABLE 2.4

\section{Orchardgrass Seeded with Oats: Estimated Establishment Costs*}

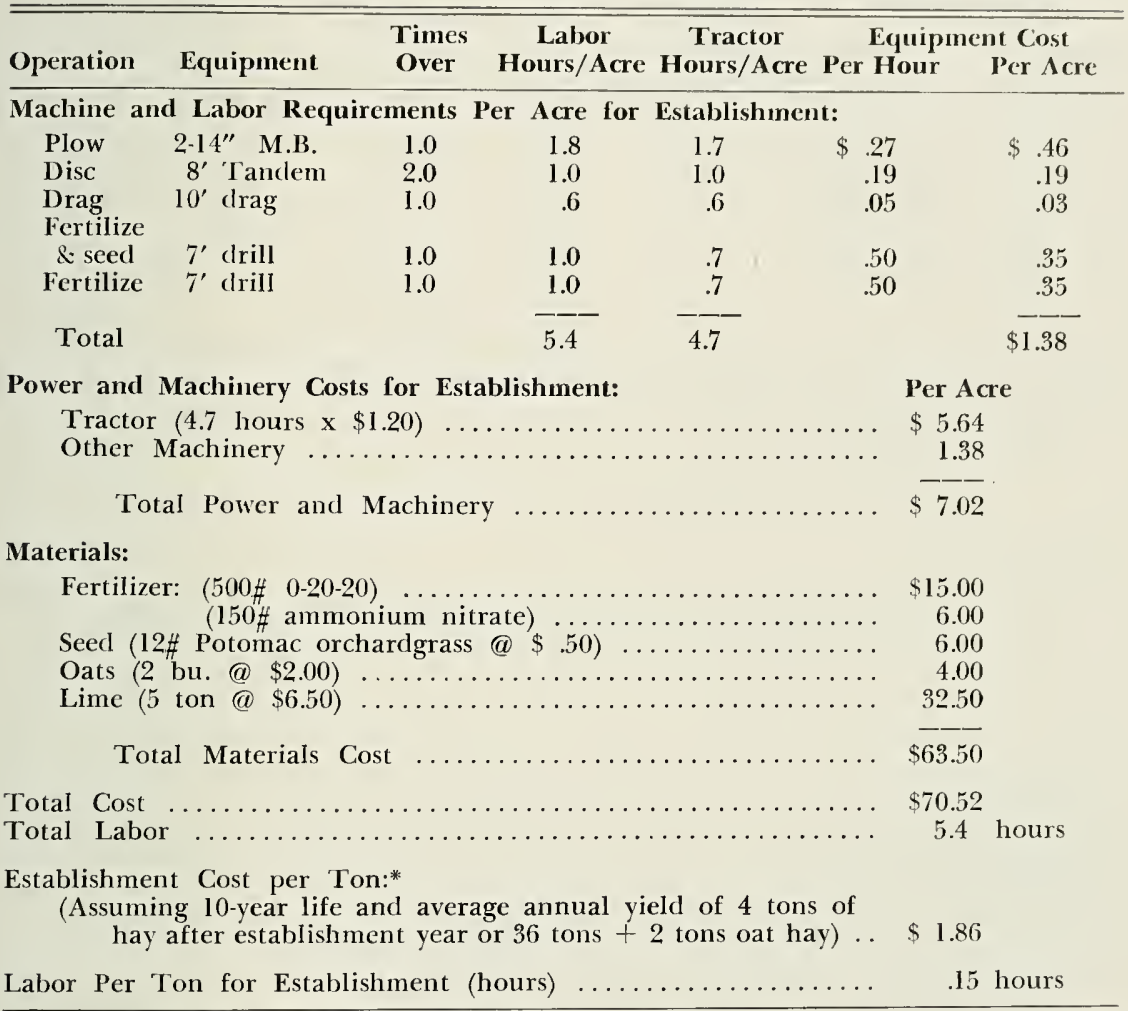

*Excludes fixed costs of machinery, land, and labor.

\section{Capital Requirements}

Capital requirements for livestock are included in the livestock budgets. Also included are the costs of fence and machinery. Capital required for land, buildings, and operating expenses are not included.

\section{MACHINERY INVESTMENT AND COSTS}

Machinery charges used in the forage production budgets are operrating costs only. They include the costs of fuel, lubrication, and repair. They do not include the fixed costs of depreciation, interest, housing, insurance, or taxes, as these costs are incurred whether the machinery is used for one hour or a thousand hours per year and do not vary much with use. Some of the machinery is used for several types of operations 
TABLE 2.5

\section{Orchardgrass Hay: Estimated Annual Costs*}

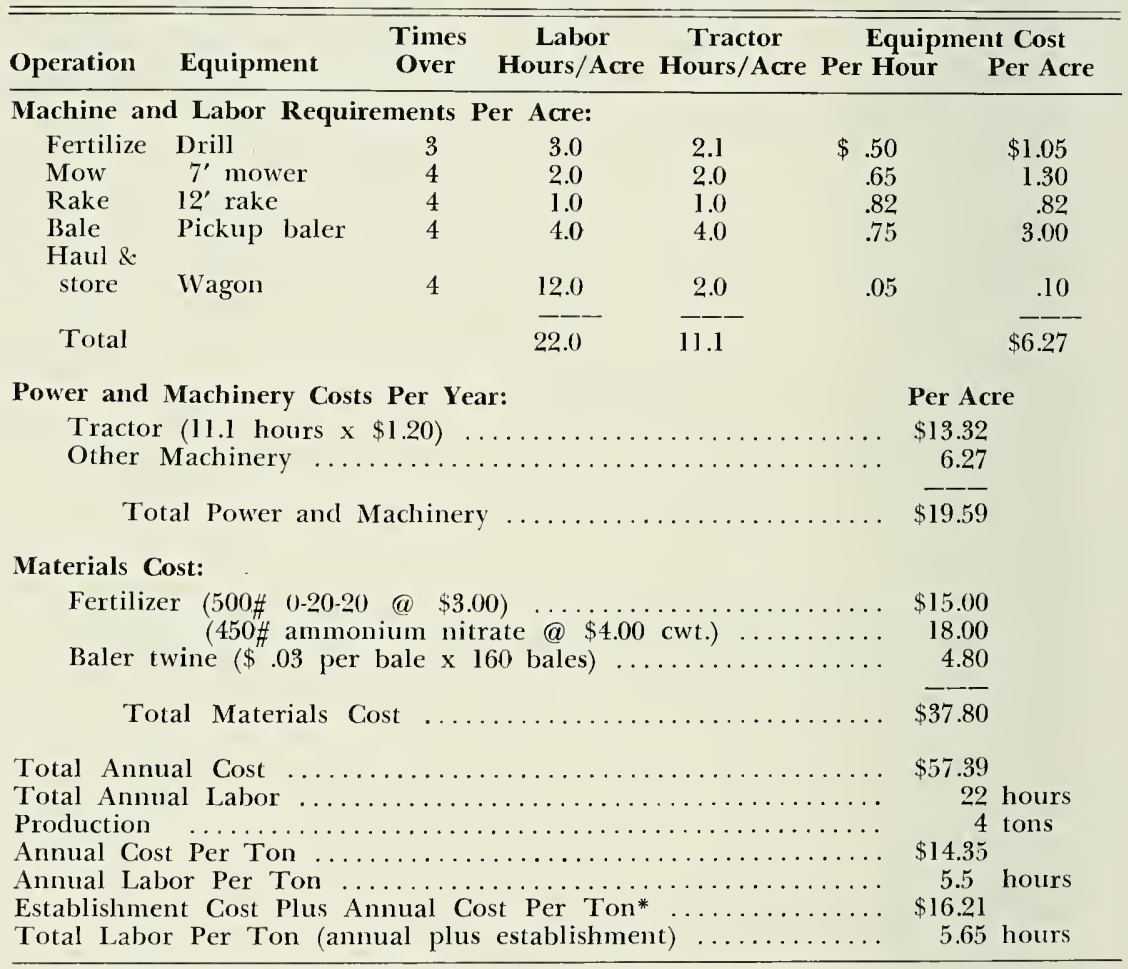

*Excludes fixed costs of machinery, land, and labor.

(for example, the tractor is used for plowing, pulling the wagon, and the manure spreader, etc.) and allocation of the costs among the various uses is difficult. Thus all fixed costs are treated as overhead to the operation of the beef cattle farm. The variable costs which are included in the budgets vary directly with acreages and uses, and are at best only rough estimates as they are influenced by steepness of the land, size of the fields and many other factors which are highly variable from farm to farm.

Table 3.1 lists estimated costs and depreciation for the minimum machinery needed for a 50 -cow herd assuming that hay alone is produced to meet the forage requirement. With this set of machinery, annual depreciation is $\$ 993$, interest on the average investment would be $\$ 349$, (assuming a 6 per cent rate) and taxes $\$ 22$ (based on a 50 per cent assessed evaluation and a tax rate of 75 cents per $\$ 100$ evaluation). 
TABLE 2.6

Clover-Timothy Hay Seeded with Oats: Estimated Establishment Costs

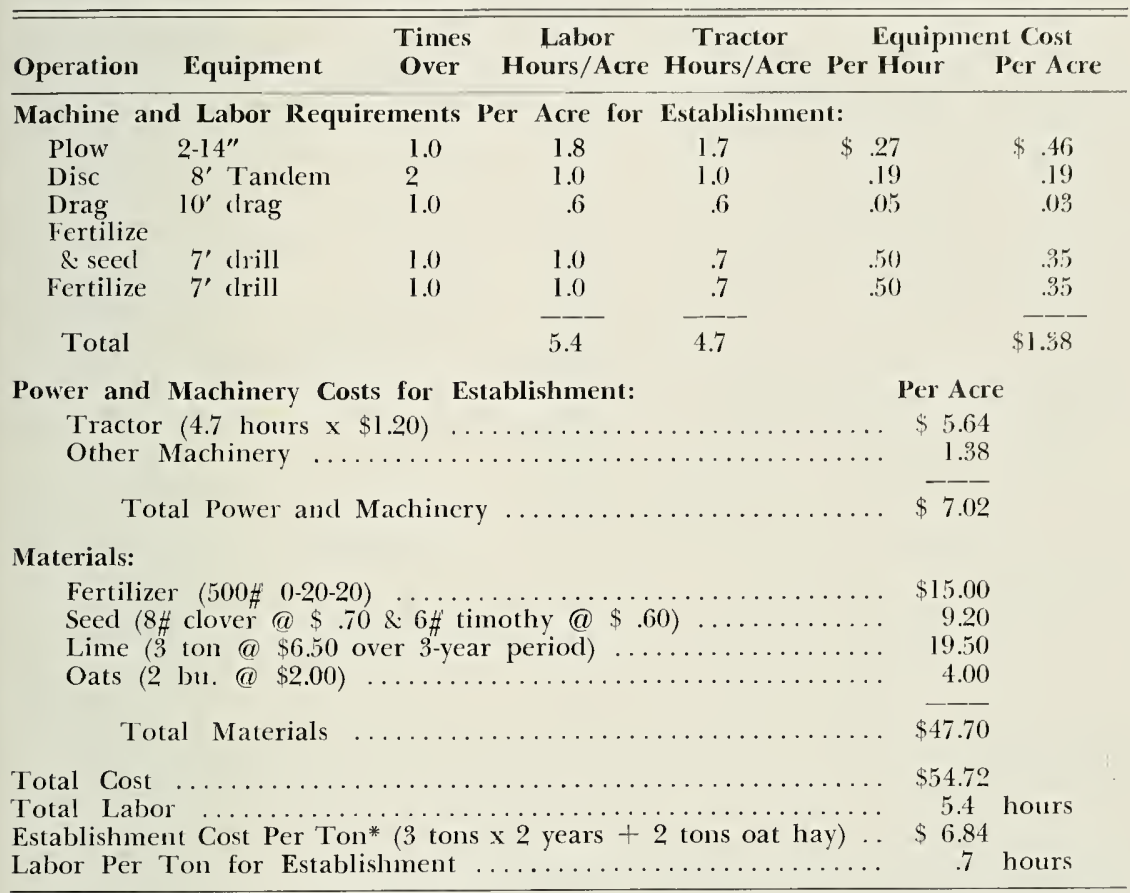

*Excludes fixed costs of machinery and labor.

Fixed machinery costs for the 50-cow herd, excluding housing and insurance for the machinery, is $\$ 1,364$ or $\$ 27.28$ per cow per year.

If silage and hay are both used to meet the forage requirement, additional machinery will be needed for harvesting the silage. Table 3.2 presents the machinery requirement for a 50-cow herd with both silage and hay equipment owned. With this set of machinery, annual depreciation is $\$ 1,377$, interest on average machinery investment would be $\$ 485$ and taxes $\$ 30$. Fixed machinery costs to make hay and silage for the 50-cow herd, excluding insurance and housing, is $\$ 1,892$ per year or $\$ 37.84$ per cow. This exceeds the cost for the hay-only system by $\$ 10.56$ per head.

One way a farmer who desires to feed both hay and silage to a 50 -cow herd can reduce the cost is to own the equipment needed specifically for silage jointly with another farmer.t This would reduce the

${ }^{+}$Purchase of used implements would lower the inrestment costs, but would likely raise the annual cost of operation as repair costs would probably be greater. 
TABLE 2.7

Clover-Timothy Hay: Estimated Annual Costs

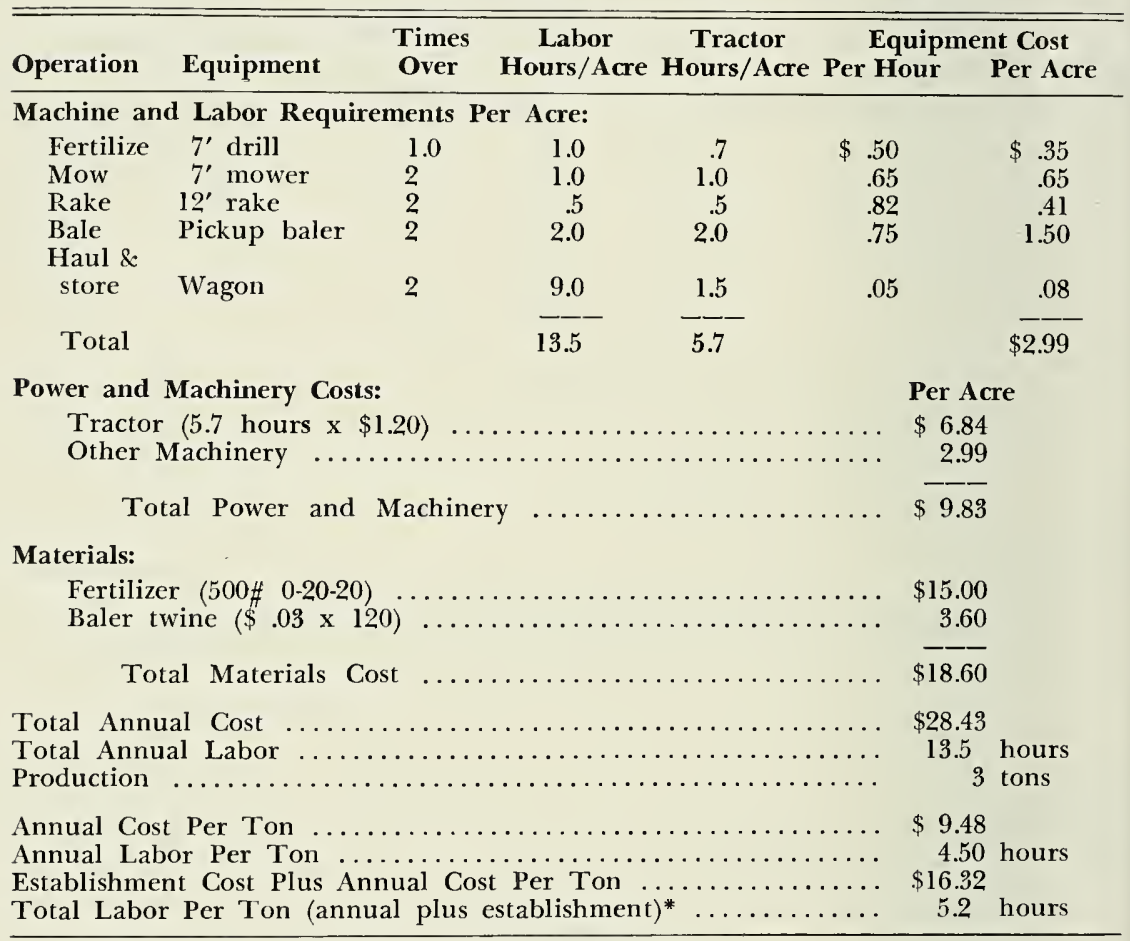

*Excludes fixed costs of machinery, land, and labor.

average investment to $\$ 6,950$ (Table 3.3). Annual depreciation would be $\$ 1,186$; interest on investment and taxes would likewise be reduced to $\$ 417$ and $\$ 26$ respectively. Fixed machinery costs per cow with $1 / 2$ ownership of silage-producing equipment and full ownership of hay equipment are $\$ 1,629$ for the 50 -cow herd or $\$ 32.58$ per cow per year$\$ 5.30$ more than the hay equipment alone but $\$ 5.26$ less than with full ownership of both hay and silage equipment.

As the basic set of machinery listed is the minimum required for producing hay and silage whether an individual has 30 cows or 50 , the total investment in machinery can be reduced only by joint ownership or custom work. Many farmers are unwilling to own machinery jointly or custom-hire work due to timeliness of operation, and other reasons. Thus, their alternative is to spread the given machinery costs over a greater number of cows. Tables 3.4 and 3.5 present the machinery investment for a herd of 100 cows using hay only and hay and silage for 
TABLE 2.8

Corn Silage: Estimated Costs*

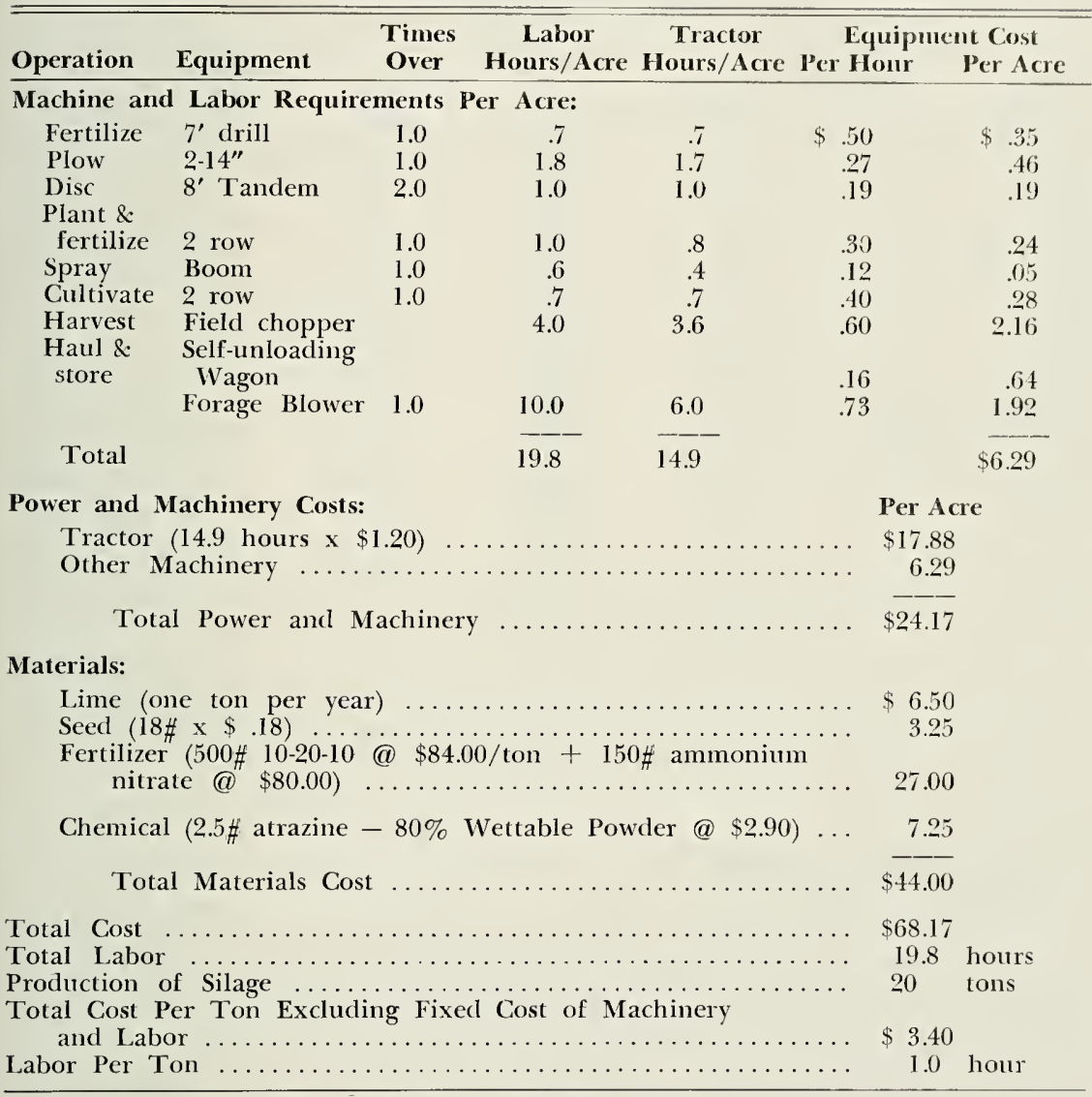

*Excludes fixed costs of machinery, land, and labor.

forage. The only additional equipment necessitated to produce the forage and to perform other operations for a 100-cow herd would be an additional tractor and wagon and perhaps a larger pickup truck. If hay alone is produced for forage, annual fixed machinery costs are $\$ 1,273$ for depreciation, $\$ 464$ for interest and $\$ 29$ for taxes-a total of $\$ 1,766$ for the 100-cow herd. The fixed machinery cost per cow is $\$ 17.66$ or $\$ 9.62$ less per cow than the cost for a 50-cow herd. If both hay and silage are produced and full ownership of all machinery is assumed, annual machinery depreciation is $\$ 1,657$, interest $\$ 600$, and taxes $\$ 38$, or a total of $\$ 2,295$ for the 100 -cow herd or $\$ 22.95$ per cors. 


\section{TABLE 3.1}

\section{Machinery for 50-Cow Herd}

(Hay Only)

\begin{tabular}{|c|c|c|c|c|c|}
\hline Machine & Cost & \multicolumn{2}{|r|}{$\begin{array}{l}\text { Estimated } \\
\text { Years } \\
\text { Life* }\end{array}$} & \multicolumn{2}{|c|}{$\begin{array}{l}\text { Annual } \\
\text { Deprec. }\end{array}$} \\
\hline Tractor & $\$ 3,200$ & $\$ 1,600$ & 15 & $\$$ & 213 \\
\hline Plow. & 300 & 150 & 15 & & 20 \\
\hline Disc $\ldots \ldots$ & 330 & 165 & 15 & & 22 \\
\hline Grain Drill .. & 650 & 325 & 20 & & 32 \\
\hline Sprayer...... & 200 & 100 & 10 & & 20 \\
\hline Mower $\ldots$ & 540 & 270 & 12 & & 45 \\
\hline Rake . & 560 & 280 & 12 & & 47 \\
\hline Baler . & 2,300 & 1,150 & 10 & & 230 \\
\hline Wagon $\ldots \ldots \ldots \ldots \ldots \ldots \ldots \ldots$ & 250 & 125 & 15 & & 17 \\
\hline Manure Spreader $\ldots \ldots \ldots \ldots \ldots$ & 600 & 300 & 15 & & 40 \\
\hline Manure Loader. & 300 & 150 & 10 & & 30 \\
\hline Elevator $\ldots \ldots \ldots \ldots$ & 400 & 200 & 15 & & 27 \\
\hline Truck $(1 / 2$ Ton $) \ldots \ldots \ldots \ldots \ldots$ & 2,000 & 1,000 & 8 & & 250 \\
\hline Total $\ldots \ldots \ldots$ & $\$ 11,630$ & $\$ 5,815$ & & & 993 \\
\hline \multirow{2}{*}{\multicolumn{4}{|c|}{$\begin{array}{l}\text { Interest on average investment }(6 \% \text { x } \$ 5,815) \ldots \ldots \ldots \ldots \\
\text { Taxes }(1 / 2 \text { of average value } \times 75 \text { cents per } \$ 100 \text { or } \$ 29 \times \$ .75)\end{array}$}} & $\$$ & $\begin{array}{r}349 \\
99\end{array}$ \\
\hline & & & & & 22 \\
\hline Total fixed machinery cost per year & year & & & & $\begin{array}{r}, 364 \\
27.28\end{array}$ \\
\hline
\end{tabular}

*Source: Agricultural Engineers' Yearbook, 1962, 1964.

\section{LAND INVESTMENT}

The land requirement per cow is highly variable in West Virginia, depending upon many factors. Chief among these factors are topography fertility, rainfall, elevation, plant species and management. These factors vary greatly among areas of the State and also among farms within any given area. Cropland and pasture land requirements and corresponding investments are estimated in Table 4.

\section{Cropland Requirements}

For any given farm, the amount of cropland required will be influenced not only by the productivity of the land and average rainfall, but by the selection of crops used alone or in rotation to produce the forage required by the herd. If corn silage, oats and alfalfa-mixed hay are produced in rotation $-1 / 7$ of the cropland in corn, $1 / 7$ in oats seeded with alfalfa and cut for hay, and $5 / 7$ in alfalfa-mixed hay-and average yields are those estimated in the crop budgets, the cropland requirement is approximately 42 acres per 100 cows. If alfalfa-mixed hay alone is produced with oats seeded as a nurse crop and cut for hay, 
TABLE 3.2

Machinery for 50-Cow Herd

(Silage \& Hay)

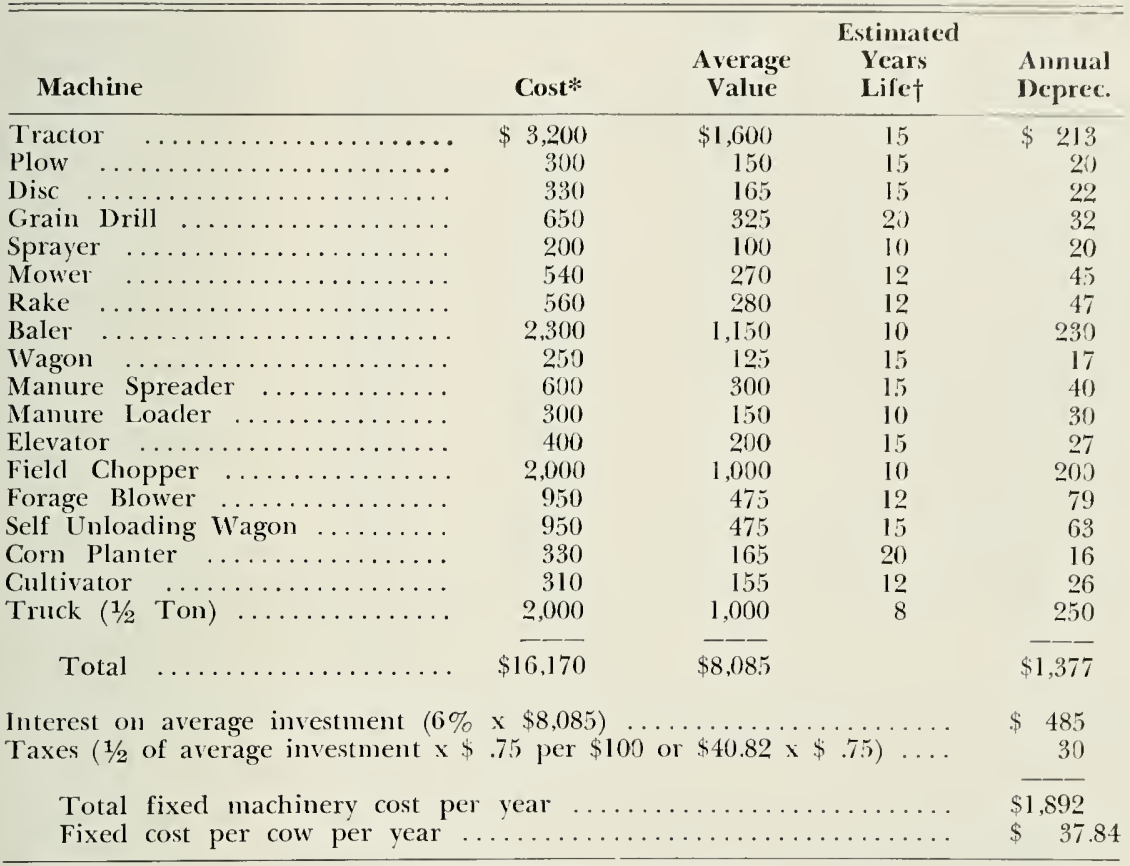

*Source: Agricultural Engineers' Yearbook, 1962, 1964.

the cropland requirement is about 44 acres per 100 cows. If the rotation is corn silage, oats and clover-mixed hay, the requirement is about 55 acres per 100 cows. The cost of cropland will also vary greatly between and within areas depending upon productivity, slope and location. In this analysis an average value of $\$ 400$ per acre is assumed for cropland from which yields equivalent to those assumed in the budgets can be obtained.

\section{Pasture Land Requirements}

Pasture land requirements will vary even more than cropland requirements with the acreage required depending upon fertility level, plant species, soil type, rainfall, and many other factors. In the limestone areas with average rainfall and high fertility, two acres of pasture land per cow in the herd should be adequate to provide pasture for seven months each year. However, in other areas with unimproved pastures this requirement may exceed six acres or more per cow. The initial cost 
TABLE 3.4

Minimum Machinery for a 100-Cow Herd

(Hay Only)

\begin{tabular}{|c|c|c|c|c|c|}
\hline Machine & Cost & $\begin{array}{c}\text { Average } \\
\text { Value }\end{array}$ & $\begin{array}{c}\text { Estimated } \\
\text { Years } \\
\text { Life* }\end{array}$ & & $\begin{array}{l}\text { nnual } \\
\text { eprec. }\end{array}$ \\
\hline 2 Tractors & $\$ 6,400$ & $\$ 3,200$ & 15 & $\$$ & 427 \\
\hline$\ldots \ldots \ldots \ldots$ & 300 & 150 & 15 & & 20 \\
\hline Disc & 330 & 165 & 15 & & 22 \\
\hline Grain Drill & 650 & 325 & 20) & & 32 \\
\hline Sprayer $\ldots \ldots \ldots \ldots \ldots \ldots \ldots \ldots$ & 200 & 100 & 10 & & 20 \\
\hline Mower $\quad \ldots \ldots \ldots \ldots \ldots \ldots \ldots$ & 540 & 270 & 12 & & 45 \\
\hline Rake. & 560 & 280 & 12 & & 47 \\
\hline Baler .... & 2,300 & $\mathrm{I}, \mathrm{I} 50$ & 10 & & 230 \\
\hline 2 Wagons ....... & 500 & 250 & 15 & & 33 \\
\hline Manure Spreader & 600 & 300 & 15 & & 40 \\
\hline Manure Loader . & 300 & 150 & 10 & & 30 \\
\hline Elevator $\ldots \ldots \ldots$. & 400 & 200 & 15 & & 27 \\
\hline Truck $(3 / 4$ Ton $)$ & 2,400 & 1.200 & 8 & & 300 \\
\hline Total $\ldots \ldots \ldots \ldots \ldots \ldots$ & $\$ 15,480$ & $\$ 7,740$ & & & 1,273 \\
\hline \multirow{2}{*}{\multicolumn{4}{|c|}{$\begin{array}{l}\text { Interest on average investment }\left(6 \% \times \frac{x}{} \$ 7,740\right) \\
\text { Taxes }(1 / 2 \text { of average investment } \times \$ .75 \text { per } \$ 100 \text { or } \$ 38.70 \times \$ .75) \ldots \ldots\end{array}$}} & \multirow{2}{*}{\multicolumn{2}{|c|}{$\begin{array}{rr}\$ \quad 464 \\
& 29\end{array}$}} \\
\hline & & & $.75) \ldots$ & & \\
\hline \multirow{2}{*}{\multicolumn{4}{|c|}{ Total fixed machinery cost per year }} & \multicolumn{2}{|c|}{$\$ 1,766$} \\
\hline & & & & & 17.66 \\
\hline
\end{tabular}

*Source: Agricultural Engineers' Yerrbook, 1962, 1964.

fence the land area required for a 50-cow herd would require approximately 3 miles of fence.

In reality, only a part of this fence would be built each year, but the life of the posts and fence normally require that all of it be replaced in a period of 20 years. Annual repairs will also be required; these are estimated to require 10 hours of labor and $\$ 2.50$ for materials per mile annually. The estimated annual cost to establish and maintain a fence is $\$ 2.40$ per cow.

\section{BUILDING INVESTMENT}

Farm buildings found on beef cattle farms in West Virginia range from large masonry barns and large automatic feeding silos to open sheds with trench silos or converted dairy barns. Thus, the existing investment in buildings is highly variable. On most farms in West Virginia with a minimum of 50 cows, existing barns are more than adequate, and in many cases have been fully depreciated. The investment required and annual cost of maintaining adequate buildings for a 50-cow herd are shown in Table 6 . A total investment of $\$ 110$ per cow in buildings and 
TABLE 3.5

Minimum Machinery for a 100-Cow Herd

(Silage \& Hay)

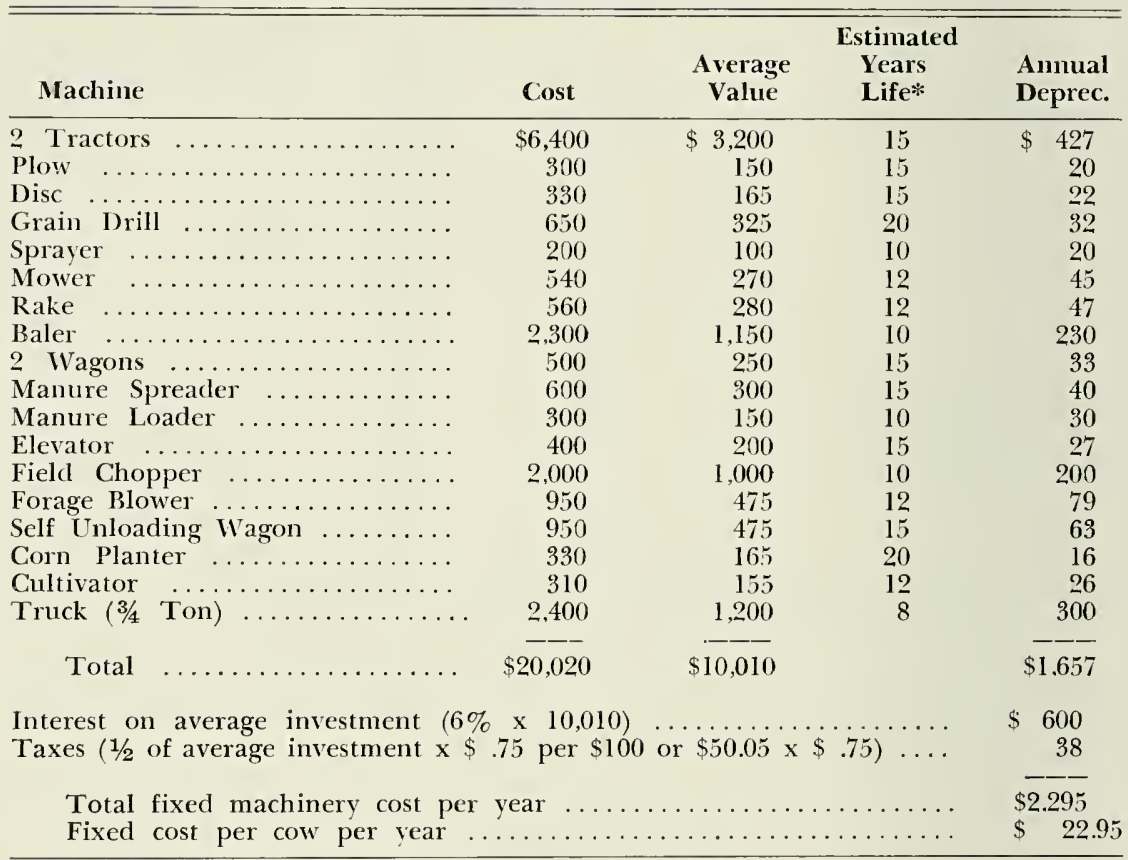

*Source: Agricultural Engineers' Yearbook, 1962, 1964.

silos is estimated, or a cost of $\$ 8.60$ per cow year to depreciate the buildings in 30 years, obtain a return of 6 per cent on the average investment, and to pay taxes, insurance, and repairs. If the silo is omitted, the investment is $\$ 80$ per cow or a cost of $\$ 6.26$ per cow per year.

\section{BULL DEPRECIATION}

In the livestock budgets, the cost of bulls is assumed to be $\$ 500$, and it is assumed that the bulls have an average of four years useful service. The salvage value is assumed to be $\$ 256$ (1,600 pounds $\mathrm{x} 16$ cents per pound). Thus, the average value is about $\$ 375$ and annual depreciation is $\$ 61$ per bull.

\section{Gross Income}

Gross income from a beef cow herd of given size varies greatly from year to year. Weight of calves sold and price received per pound are the two factors which are chiefly responsible for this variation. 
TABLE 4

Estimated Land Investment for a 100-Cow Herd*

\begin{tabular}{|c|c|c|c|c|}
\hline \multirow{2}{*}{$\begin{array}{l}\text { Cropland: } 50 \text { acres@ } \$ 400 / \text { acro } \\
\text { Pasture Land: }\end{array}$} & \multicolumn{4}{|c|}{ Type of Soil } \\
\hline & $\begin{array}{l}\text { Improved } \\
\text { Limestone }\end{array}$ & $\begin{array}{l}\text { Unimproved } \\
\text { Limestone }\end{array}$ & $\begin{array}{l}\text { Improved } \\
\text { Non- } \\
\text { Limestone }\end{array}$ & $\begin{array}{l}\text { Unimproved } \\
\text { Non- } \\
\text { Limestone }\end{array}$ \\
\hline Acres Necded ..... & 200 & 400 & 300 & 600 \\
\hline \multicolumn{5}{|l|}{ Estimated Cost per } \\
\hline Acre Before Improved ...... & . 80 & 80 & 50 & 50 \\
\hline Pasture Land Invest. ......... & $\$ 16,000$ & $\$ 32,000$ & $\$ 15,000$ & $\$ 30,000$ \\
\hline Improvement Practice/Acre .... & $\begin{array}{r}400 \# 10-20-0 \\
\text { per } 4 \text { years }\end{array}$ & 0 & $\begin{array}{c}300 \# 14-56-0 \\
\text { plus } 2 \text { tons } \\
\text { lime per } 4 \\
\text { years }\end{array}$ & 0 \\
\hline $\begin{array}{l}\text { Estimated Cost of } \\
\text { Improvement/acre/year } \ldots . . .\end{array}$ & $\$ 3.20$ & 0 & $\$ 7.50$ & 0 \\
\hline $\begin{array}{l}\text { Cost to Farmer Assuming ACP } \\
\text { Payment of } 50 \text { Per Cent } \ldots .\end{array}$ & $\$ 1.60$ & & $\$ 3.75$ & \\
\hline
\end{tabular}

Alternative Land Investments:

(1) 50 acres Cropland and 200 acres Improved Limestone ..... $\$ 36,000$

(2) 50 acres Cropland and 300 acres Unimproved Limestone ..... 52,000

(3) 50 acres Cropland and 300 acres Improved Non-Limestone ... 35,000

(4) 50 acres Cropland and 600 acres Unimproved Non-Limestone .. 50,000 herd.

*Land requirements for a 50 -cow herd would be just about $1 / 2$ that for the 100 -cow

TABLE 5

\section{Estimated Costs of Fencing Pasture and Cropland Required for a 50-Cow Beef Herd}

\begin{tabular}{|c|c|c|c|c|}
\hline Item & Unit & Quantity & Price & Cost \\
\hline Barbed Wire* & Miles & 3 & $\$ 44.00 * *$ & $\$ 132.00$ \\
\hline Woven Wire & Miles & 3 & $320.00^{* * * *}$ & 960.00 \\
\hline Locust Posts & Number & $1,320 \dagger$ & .40 & 528.00 \\
\hline Corner Braces & Number & 40 & .50 & 20.00 \\
\hline Gates & Number & 8 & 20.00 & 160.00 \\
\hline Staples & Pounds & 100 & .20 & 20.00 \\
\hline Labor & Hours & 600 & .75 & 450.00 \\
\hline
\end{tabular}

Annual Costs:

Depreciation $\div \div$

Annual Repair

Labor

Mile

Mile

3

2.50

10 hours

Total Specified Annual Cost (excluding labor)

Annual Cost Per Cow (excluding amnual labor) .............. 2.40

*Assumes a single strand of barbed wire over 39-inch woven wire.

**Assumes a price of $\$ 11.00$ per 80 -rod roll aud 4 rolls per mile.

***Assumes a price of $\$ 20.00$ per 20 -rod roll and 16 rolls per mile.

+Assumes a 12-foot spacing.

$+\dagger$ Assumes an average life of 20 years. 


\section{TABLE 6}

\section{Building Investment for a 50-Cow Beef Herd}

\begin{tabular}{|c|c|c|}
\hline 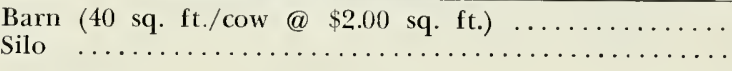 & $\begin{array}{r}\$ 4,000.00 \\
1,500.00\end{array}$ & \\
\hline Total & $\$ 5,500.00$ & \\
\hline Annual Costs: & With Silo & $\begin{array}{l}\text { Without } \\
\text { Silo }\end{array}$ \\
\hline Depreciation (assuming a 30-year life) & $\$ 183.00$ & $\$ 133.00$ \\
\hline Interest on Average Investment* $\ldots \ldots \ldots$ & 165.00 & 120.00 \\
\hline Taxes \& Insurance $\dagger \ldots \ldots \ldots \ldots \ldots \ldots$ & 82.00 & 60.00 \\
\hline Total Annual Costs ....... & $\$ 430.00$ & $\$ 313.00$ \\
\hline Annual Cost per Cow & 8.60 & 6.26 \\
\hline
\end{tabular}

*Assuming an interest rate of 6 per cent on one-half investment. $\uparrow$ Assuming a rate of 3 per cent of average investment.

\section{WEIGHT}

The variation in the weight of calves available for sale from a herd is caused by (1) weather which affects the quantity and quality of forage available and (2) the number of calves weaned. The farmer cannot control the weather, but he can control stocking rate, improve pastures, breed the herd earlier, and use other measures such as creep feeding which will increase calf weights.

\section{PRICE}

The price received per pound for calves sold is affected by (1) the quality of calves sold, (2) average weight of calves sold, and (3) the demand for and supply of calves. The individual farmer can in various ways influence both the quality and weight of calves he sells, but, individually, he can have little if any influence on either the supply or demand factors affecting price.

The effects of the per cent calf crop, the weight of calves and price received per pound on the gross return per cow in the herd are indicated in Tables 7.1, 7.2, and 7.3. With a 90 per cent calf crop, an average calf weight of 400 pounds and an average price of 25 cents per pound, gross returns per cow in the herd would be $\$ 90$; with a calf crop of 85 per cent, and the same weight and price, gross returns would be $\$ 85$ per cow in the herd. At higher prices and heavier average weights, the difference in actual dollar gross returns per cow due to the per cent calf crop is also greater. An increase in the average weight of calves, assuming price and per cent calf crop remain unchanged will also greatly increase gross returns per cow. With a 90 per cent calf crop and an average price of 25 cents per pound, gross returns per cow in the herd increase $\$ 5.62$ for each 25-pound increase in the average weight of calves sold. 

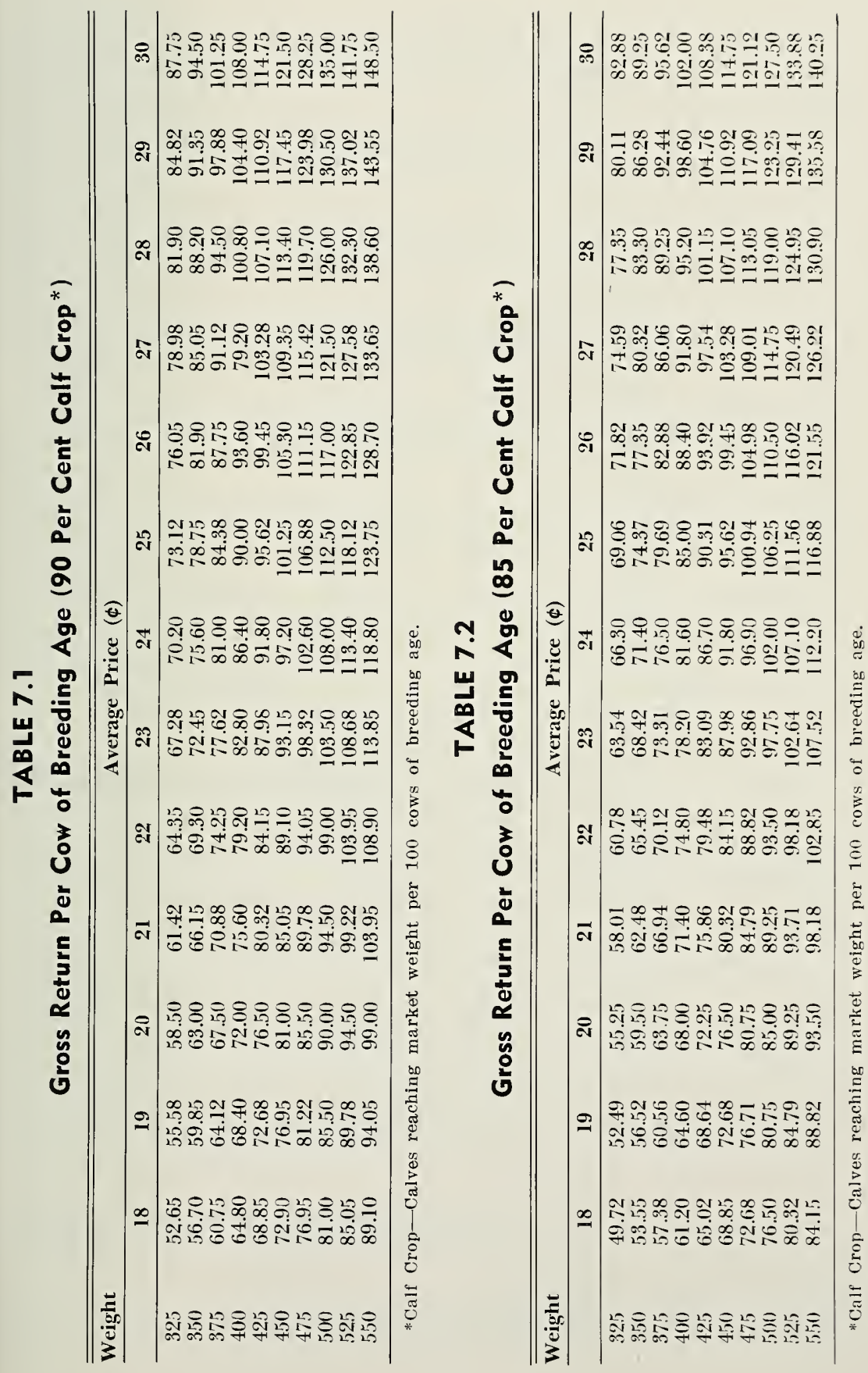


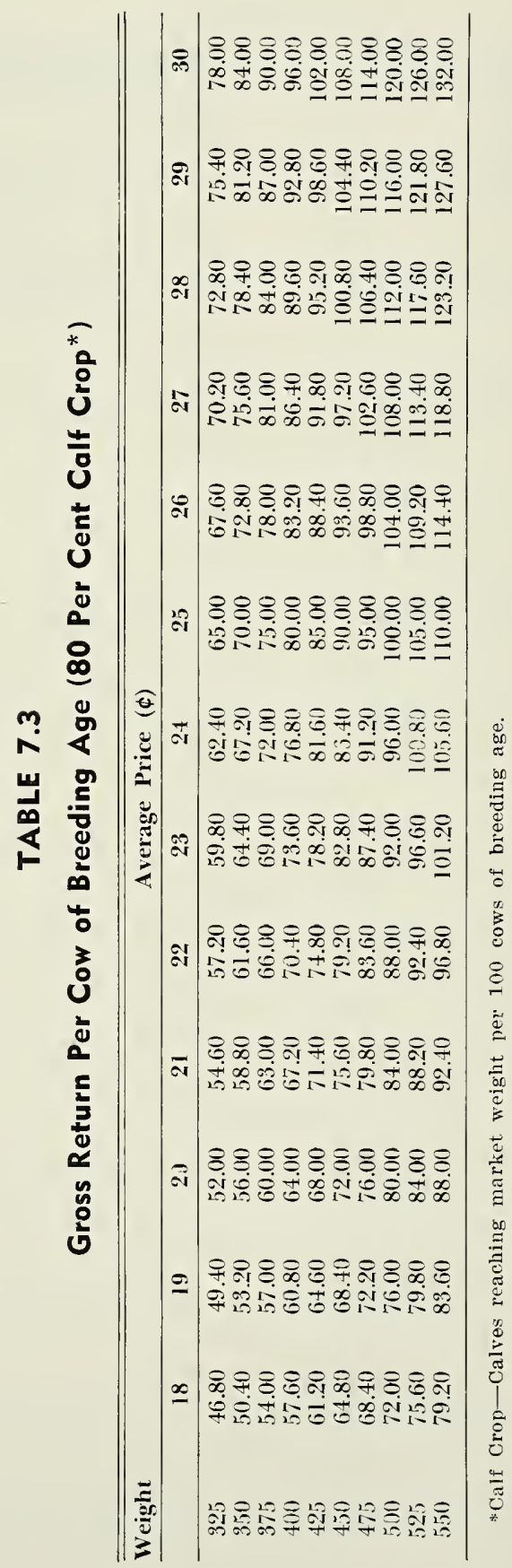


Normally, the average price which buyers are willing to pay for a given quality of calves declines as weight increases. The exact amount that buyers discount calves due to heavier weight has not been determined. However, it has been estimated that calves with an average weight of 350 pounds will normally sell for one cent per pound more than equal-quality calves with an average weight of 425 pounds (range 400 to 450 pouncls). Likewise, calves with an average weight of 425 pounds will normally sell for one cent per pound more than equalquality calves with an average weight of 475 pounds (range 450 to 500 pouncls). Calves with an average weight of 550 will sell for about $1 / 2$ cent per pound less than 450- to 500-pound calves.

Feeder calves sold through the cooperative feecler calf sales in the years 1955 to 1964 had an average weight of 420 pounds and sold for an average price of $\$ 23.91$ per hundred weight or $\$ 100.42$ per head (Táble 8). If these calves would have had an average weight of 470 pounds and been of the same quality, the average price received would have been approximately one cent per pound less or \$22.9I, but would have had an average value of $\$ 107.68$ per head. With a calf crop of 90 per cent, gross returns per cow in the herd-assuming all calves from a herd to be of equal weight and quality to those going through the feeder calf sales-were approximately $\$ 90$. With an 80 per cent calf crop, returns were only $\$ 80$ per cow.

\section{Returns to Owned Factors}

In the livestock budgets, tables 9.01 to 9.12 , returns are stated as returns to owned factors used in production. These factors are assumed to be capital invested in land, buildings, livestock, and labor and management. Thus, these returns are the amount by which gross returns exceed cash expenses and machinery depreciation. Only those expenses which a farmer must meet over a period of years have been deducted. A farmer who owns his land has adequate buildings, furnishes all or a major portion of the labor and management required, may rely on this residual for his living. Returns to management and risk can be estimated by deducting an interest cost for capital invested in land, buildings, and livestock and a charge for labor.

\section{TABLES 9.01, 9.02, AND 9.03}

In Table 9.01, the production requirements and income are presented for a 50-cow herd with a winter ration of hay only. An 80 per cent calf crop is assumed with calves reaching an average market weight of 420 pounds by October 15 . 


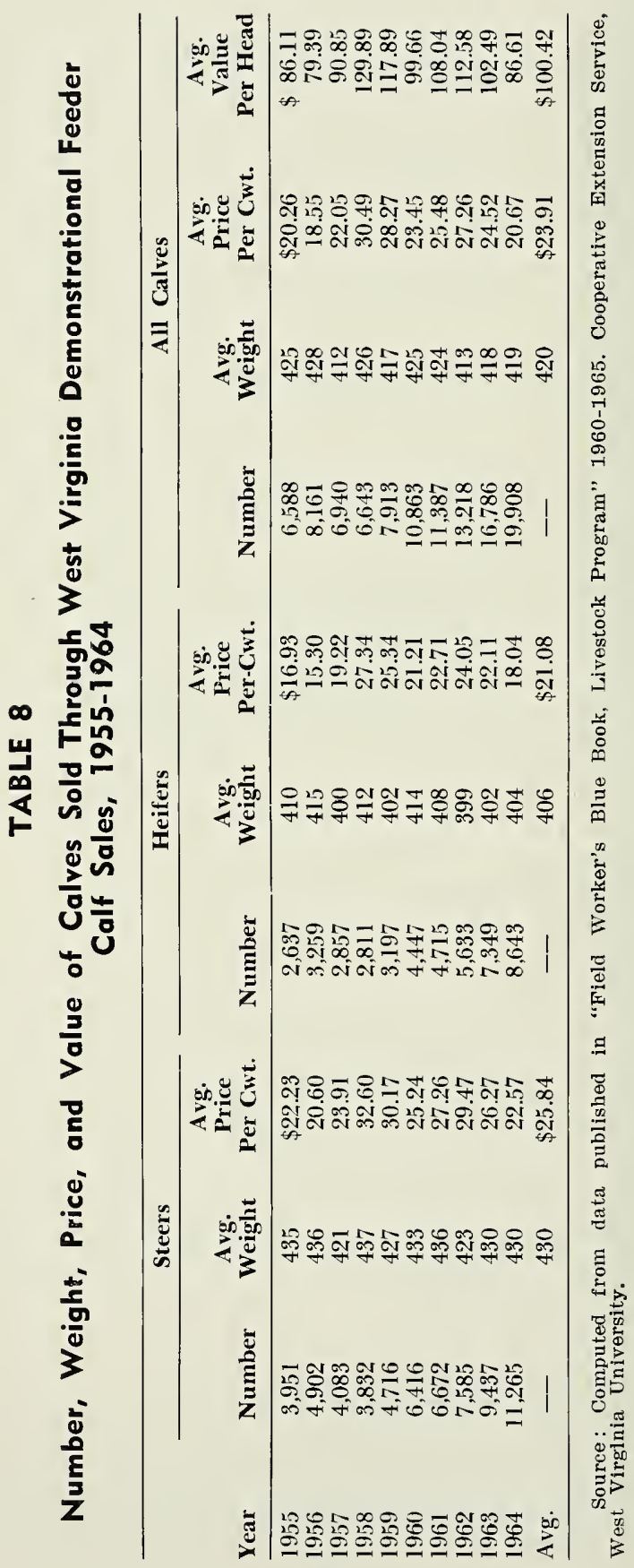


TABLE 9.01

Estimated Production Requirements and Income for a Beef Herd of 50 Cows; Winter Ration of Alfalfa-Mixed Hay; Assuming 80 Per Cent Colf Crop; Selling Feeder Colves Averaging 420 Pounds, October 15

\begin{tabular}{|c|c|c|c|c|}
\hline \multicolumn{5}{|c|}{ LIVESTOCK INVESTMENT } \\
\hline Item & Head & $\begin{array}{c}\text { Animal } \\
\text { Units }\end{array}$ & $\begin{array}{c}\text { Value } \\
\text { Per Head }\end{array}$ & $\begin{array}{l}\text { Total } \\
\text { Value }\end{array}$ \\
\hline Brood cows & 50 & 50 & $\$ 175.00$ & $\$ 8,750.00$ \\
\hline Bulls $\ldots \ldots \ldots \ldots \ldots \ldots$ & 2 & 2 & 378.00 & 756.00 \\
\hline Heifers, more than 1 year. & 8 & 4 & 140.00 & $1,120.00$ \\
\hline Heifers, less than 1 year... & 8 & 2 & 100.00 & 800.00 \\
\hline Total & 68 & 58 & & $\$ 11,426.00$ \\
\hline
\end{tabular}

SALES

\begin{tabular}{lcccrr}
\hline Item & Head & Weight & Price & $\begin{array}{c}\text { Value } \\
\text { Per Head }\end{array}$ & $\begin{array}{r}\text { Total } \\
\text { Value }\end{array}$ \\
\hline Cull cows $\ldots \ldots \ldots \ldots$ & 7 & 1,000 & $\$ 15.00$ & $\$ 150.00$ & $\$ 1,050.00$ \\
Heifer calves $\ldots \ldots \ldots$ & $12^{*}$ & 405 & 21.08 & 85.37 & $1,024.44$ \\
Steer calves $\ldots \ldots \ldots$ & 20 & 430 & 25.84 & 111.11 & $2,222.20$ \\
\hline
\end{tabular}

Total Receipts

$\$ 4,296.64$

INPUT ITEMS

\begin{tabular}{|c|c|c|c|c|c|c|}
\hline Item & Unit. & Rate & Number & Total & Price & $\begin{array}{l}\text { Total } \\
\text { Cost }\end{array}$ \\
\hline Pasture ........... & acres & 3 & 50 & 150 & $\$--$ & $\$--$ \\
\hline Hay (mixed alfalfa) .. & tons & & & 105 & $13.59 * *$ & $1,426.95$ \\
\hline Minerals and salt .... & lbs. & 30 & 50 & 1,500 & .03 & 45.00 \\
\hline Vet. and med. ....... & $\$$ & 2.00 & 58 & $\$ 116.00$ & & 116.00 \\
\hline Bull depreciation .... & $\$$ & 61.00 & 2 & $\$ 122.00$ & & 122.00 \\
\hline Hauling \& marketing & cwt. & & 204 & & .75 & 153.00 \\
\hline Tax on livestock .... & $\$ 100$ as & sessed & & & & 3000 \\
\hline Machi & Eval. $t$ & $\begin{array}{r}.70 \\
27.28\end{array}$ & $\begin{array}{l}57 \\
50\end{array}$ & $\$ 1,364.00$ & & $\begin{array}{r}39.90 \\
1,364.00\end{array}$ \\
\hline $\begin{array}{l}\text { Macninery } \\
\text { Fencing } \ldots\end{array}$ & $\$ /$ cow & 2.40 & 50 & $\$ 120.00$ & & 120.00 \\
\hline Total of Specified & Costs. & & & & & $\$ 3,386.85$ \\
\hline Returns to Owned & Factors & & & & & $\$ 909.79$ \\
\hline Returns Per Cow & Above & Specifies & Costs & & $\ldots \ldots \ldots$ & $\$ \quad 18.20$ \\
\hline
\end{tabular}

*Assuming eight heifers kept for replacement.

* * Includes variable costs of production only.

tAssessed evaluation equal to 50 per cent of actual value.

The livestock investment consists of 50 cows with an average value of $\$ 175$, two bulls with an average value of $\$ 378 \quad(\$ 500$ cost and $\$ 256$ salvage), 8 heifers more than one year old and 8 heifers less than one year old. The total livestock investment is estimated at $\$ 11,426$.

Sales consist of 7 cull cows, 12 heifer calves and 20 steer calves. With prices at the level received through the cooperative feeder calf sales, total sales would be $\$ 4,296.64$. Eight heifers are kept to replace the seven cows sold each year. 
TABLE 9.02

Estimated Production Requirements and Income for a Beef Herd of 50 Cows; Winter Ration of Alfalfa-Mixed Hay; Assuming 90 Per Cent Calf Crop; Selling Feeder Calves Averaging 420 Pounds, October 15

\begin{tabular}{|c|c|c|c|c|}
\hline \multicolumn{5}{|c|}{ LIVESTOCK INVESTMENT } \\
\hline Item & Head & $\begin{array}{c}\text { Animal } \\
\text { Units } \\
\end{array}$ & $\begin{array}{c}\text { Value } \\
\text { Per Head }\end{array}$ & $\begin{array}{l}\text { Total } \\
\text { Value }\end{array}$ \\
\hline $\begin{array}{l}\text { Brood cows .. } \\
\text { Bulls }\end{array}$ & 50 & 50 & $\$ 175.00$ & $\$ 8,750.00$ \\
\hline Bulls $\ldots \ldots \ldots \ldots \ldots \ldots$ & 2 & 2 & 378.00 & 756.00 \\
\hline Heifers, more than 1 year. & 8 & 4 & 140.00 & $1,120.00$ \\
\hline Heifers, less than 1 year .. & 8 & 2 & 100.00 & 800.00 \\
\hline Total & 68 & 58 & & $\$ 11,426.00$ \\
\hline
\end{tabular}

SALES

\begin{tabular}{|c|c|c|c|c|c|}
\hline Item & Head & Weight & Price & $\begin{array}{c}\text { Value } \\
\text { Per Head }\end{array}$ & $\begin{array}{l}\text { Total } \\
\text { Value }\end{array}$ \\
\hline Cull cows .. & 7 & 1,000 & $\$ 15.00$ & $\$ 150.00$ & $\$ 1,050.00$ \\
\hline Heifer calves & $14^{*}$ & 405 & 21.08 & 85.37 & $1,195.18$ \\
\hline Steer calves. & 23 & 430 & 25.84 & 111.11 & $2,555.53$ \\
\hline
\end{tabular}

INPUT ITEMS

\begin{tabular}{|c|c|c|c|c|c|c|}
\hline Item & Unit & Rate & Number & Total & Frice & $\begin{array}{l}\text { Total } \\
\text { Cost }\end{array}$ \\
\hline Pasture & acres & 3 & 50 & 150 & $\$--$ & $\$-1$ \\
\hline Hay $\ldots \ldots \ldots \ldots \ldots$ & tons & & & 105 & $13.59 * *$ & $1,426.95$ \\
\hline Minerals and salt $\ldots$. & Ibs. & 30 & 50 & 1,500 & .03 & 45.00 \\
\hline Vet. and med. ...... & $\$$ & 2.00 & 58 & $\$ 116.00$ & & 116.00 \\
\hline BuII depreciation .... & $\$$ & 61.00 & 2 & $\$ 122.00$ & & 122.00 \\
\hline Hauling \& marketing & cwt. & & 226 & & .75 & 169.50 \\
\hline Tax on livestock .... & $\begin{array}{l}\$ 100 \text { as } \\
\text { eval }\end{array}$ & $\begin{array}{r}\text { iessedl } \\
70\end{array}$ & 746 & $\$ 3900$ & & (107.00 \\
\hline Machinery & $\$ /$ cow & 27.28 & 50 & $\$ 1,364.00$ & & 1.364 .00 \\
\hline Fencing . & $\$ /$ cow & 2.40 & 50 & $\$ 120.00$ & & 120.00 \\
\hline \multirow{2}{*}{\multicolumn{6}{|c|}{$\begin{array}{l}\text { Total of Specified Costs } \ldots \ldots \ldots \ldots \ldots \\
\text { Returns to Owned Factors } \ldots \ldots \ldots \ldots\end{array}$}} & $\$ 3,403.35$ \\
\hline & & & & & & $\$ 1,397.36$ \\
\hline \multicolumn{6}{|c|}{ Returns Per Cow Above Specified Costs } & $\$ \quad 27.95$ \\
\hline
\end{tabular}

*Assuming eight heifers kept for replacement.

* * Includes variable costs of production only.

tAssessed evaluation equal to 50 per cent of actual value.

Requirements are estimated to be 150 acres of pasture, 105 tons of hay, 1,500 pounds of mineralized salt, and $\$ 2.00$ per animal unit for veterinary and medical expenses. Bull depreciation at $\$ 61.00$ per bull, a hauling and marketing cost of 75 cents per hundred weight marketed, taxes on livestock of $\$ .70$ per $\$ 100$ assessed evaluation, and a fencing cost of $\$ 2.40$ per cow constitute other costs which will be incurred. Total costs are $\$ 3,386.85$, exclusive of pasture costs, labor, land costs, and 
TABLE 9.03

Estimated Production Requirements and Income for a Beef Herd of 50 Cows; Selling Feeder Calves, Winter Ration of Alfalfa-Mixed Hay; Assuming 90 Per Cent Calf Crop; Selling Feeder Calves Averaging 470 Pounds, October 15

\begin{tabular}{|c|c|c|c|c|}
\hline \multicolumn{5}{|c|}{ LIVESTOCK INVESTMENT } \\
\hline Item & Head & $\underset{\text { Unimal }}{\text { Animal }}$ & $\begin{array}{c}\text { Value } \\
\text { Per Head }\end{array}$ & $\begin{array}{l}\text { Total } \\
\text { Value }\end{array}$ \\
\hline Brood cows ... & 50 & 50 & $\$ 175.00$ & $\$ 8,750.00$ \\
\hline Bulls $\ldots \ldots \ldots \ldots \ldots \ldots$ & 2 & 2 & 378.00 & 756.00 \\
\hline Heifers, more than 1 year. & $\overline{8}$ & 4 & 140.00 & $\mathbf{1}, 120.00$ \\
\hline Heifers, less than 1 year ... & 8 & 2 & 100.00 & 800.00 \\
\hline Total & 68 & 58 & & $\$ 11,426.00$ \\
\hline
\end{tabular}

SALES

\begin{tabular}{|c|c|c|c|c|c|}
\hline Item & Head & Weight & Price & $\begin{array}{l}\text { Value } \\
\text { Per Head }\end{array}$ & $\begin{array}{l}\text { Total } \\
\text { Value }\end{array}$ \\
\hline Cull cows & 7 & 1,000 & $\$ 15.00$ & $\$ 150.00$ & $\$ 1,050.00$ \\
\hline Heifer calves & $14^{*}$ & 455 & 20.08 & 91.36 & 1.279 .04 \\
\hline Steer calves & 23 & 485 & 24.84 & 120.47 & $2,770.81$ \\
\hline
\end{tabular}

INPUT ITEMS

\begin{tabular}{|c|c|c|c|c|c|c|}
\hline Item & Unit & Rate & Number & Total & Price & $\begin{array}{l}\text { Total } \\
\text { Cost }\end{array}$ \\
\hline Pasture & acres & 3 & 50 & 150 & $\$--$ & $\$-\ldots$ \\
\hline Hay $\ldots \ldots \ldots . . . .$. & tons & & & 111 & $13.59 * *$ & $1,508.49$ \\
\hline Minerals and salt & lbs. & 30 & 50 & 1,500 & .03 & 45.00 \\
\hline Vet. and med. . & $\$$ & 2.00 & .58 & $\$ 116.00$ & & 116.00 \\
\hline Bull depreciation .... & $\$$ & 61.00 & 2 & $\$ 122.00$ & & 122.00 \\
\hline Hauling \& marketing & cwt. & & 245 & $\$ 183.75$ & .75 & 183.75 \\
\hline Tax on livestock .... & $\$ 100$ as & sessed & & & & \\
\hline & eval. $\dagger$ & .70 & 57 & $\$ 39.90$ & & $\begin{array}{r}39.90 \\
86400\end{array}$ \\
\hline Machinery & $\$ /$ cow & 27.28 & 50 & $\$ 1,364.00$ & & $1,364.00$ \\
\hline Fencing .. & $\$ /$ cow & 2.40 & 50 & $\$ 120.00$ & & 120.00 \\
\hline \multicolumn{6}{|c|}{ Total of Specified Costs } & $\$ 3,499.14$ \\
\hline \multicolumn{6}{|c|}{ Returns to Owned Factors ............ } & $\$ 1,600.71$ \\
\hline \multicolumn{6}{|c|}{ Returns Per Cow Above Specified Costs } & $\$ \quad 32.01$ \\
\hline
\end{tabular}

* Assuming eight heifers kept for replacement

* Includes variable costs of production only.

+ Assessed evaluation equal to 50 per cent of actual value.

return on investment in livestock and real estate. Returns from sales exceed specified costs by $\$ 909.79$ for a 50 -cow herd or $\$ 18.20$ per cow. This represents a return to the labor, land, buildings, livestock investment, and management.

In Table 9.02 the effect of increasing the calf crop from 80 to 90 per cent is shown. Livestock investment and most costs remain about the same, but income is increased by more than $\$ 500$. Returns per cor 
are increased by approximately $\$ 10$ per cow over the herd with an 80 per cent calf crop.

In Table 9.03, the effect of increasing the weight of calves sold by 50 pounds per calf is shown with a 90 per cent calf crop. With price reduced by one cent per pound, the heavier calves increase total sales from the 50-cow herd by $\$ 300$. The only costs assumed to be increased to get the additional 50 pounds of weight per calf are the hay costs and marketing costs. Calves must be born earlier if they are to weigh an extra 50 pounds by October 15 without grain feeding. Extra hay is included for the 45 calves.

The additional cost of producing and marketing calves weighing 50 pounds more per head would be $\$ 96$ or $\$ 203$ less for the 50-cow herd than the increased sales. The returns per cow above specified costs are increased by $\$ 4.06$ per cow by increasing the weight of calves by 50 pounds.

\section{TABLES 9.04, 9.05, AND 9.06}

In Tables 9.04, 9.05, and 9.06, production requirements and income estimates are presented for a 50-cow herd with hay and silage each comprising $1 / 2$ of the dry matter in the ration. The assumption is made that the farmer owns 100 per cent of the machinery. In Table 9.04 an 80 per cent calf crop is assumed with calves averaging 420 pounds at market. In Tables 9.05 and 9.06 a 90 per cent calf crop is assumed with calves averaging 420 pounds in Table 9.05 and 470 pounds in Table 9.06. The machinery cost is increased by $\$ 528$ above the hay-only feeding system in Tables 9.01, 9.02 and 9.03. This is only partially offset by the lower cost of producing the silage; thus, returns above specified costs are about $\$ 7$ per head less than for the hay-only systems.

For the individual with only a 50-cow herd, ownership of both hay and silage equipment is not economical unless he can increase the tonnage of silage harvested each year by custom work or unless other economies are effected. The alternative is to own the hay equipment and get the silos custom filled.

\section{TABLES 9.07, 9.08, AND 9.09}

In Tables 9.07, 9.08, and 9.09, production requirements and income are presented for a 100 -cow herd with a winter ration of hay only. The three situations budgeted are indentical to those presented in Tables 9.01, 9.02, and 9.03, except that the herd is twice as large. The sales and livestock investment are doubled, but costs, although increased, are not twice as great as for a 50-cow herd. Income above specified costs per cow for the hay-only systems with a 100 -cow herd is nearly $\$ 10$ per head 


\section{TABLE 9.04}

Estimated Production Requirements and Income for a Beef Herd of 50 Cows; Winter Ration of Alfalfa-Mixed Hay and Silage; Assuming 80 Per Cent Calf Crop; Selling Feeder Calves Weighing 420 Pounds, October 15

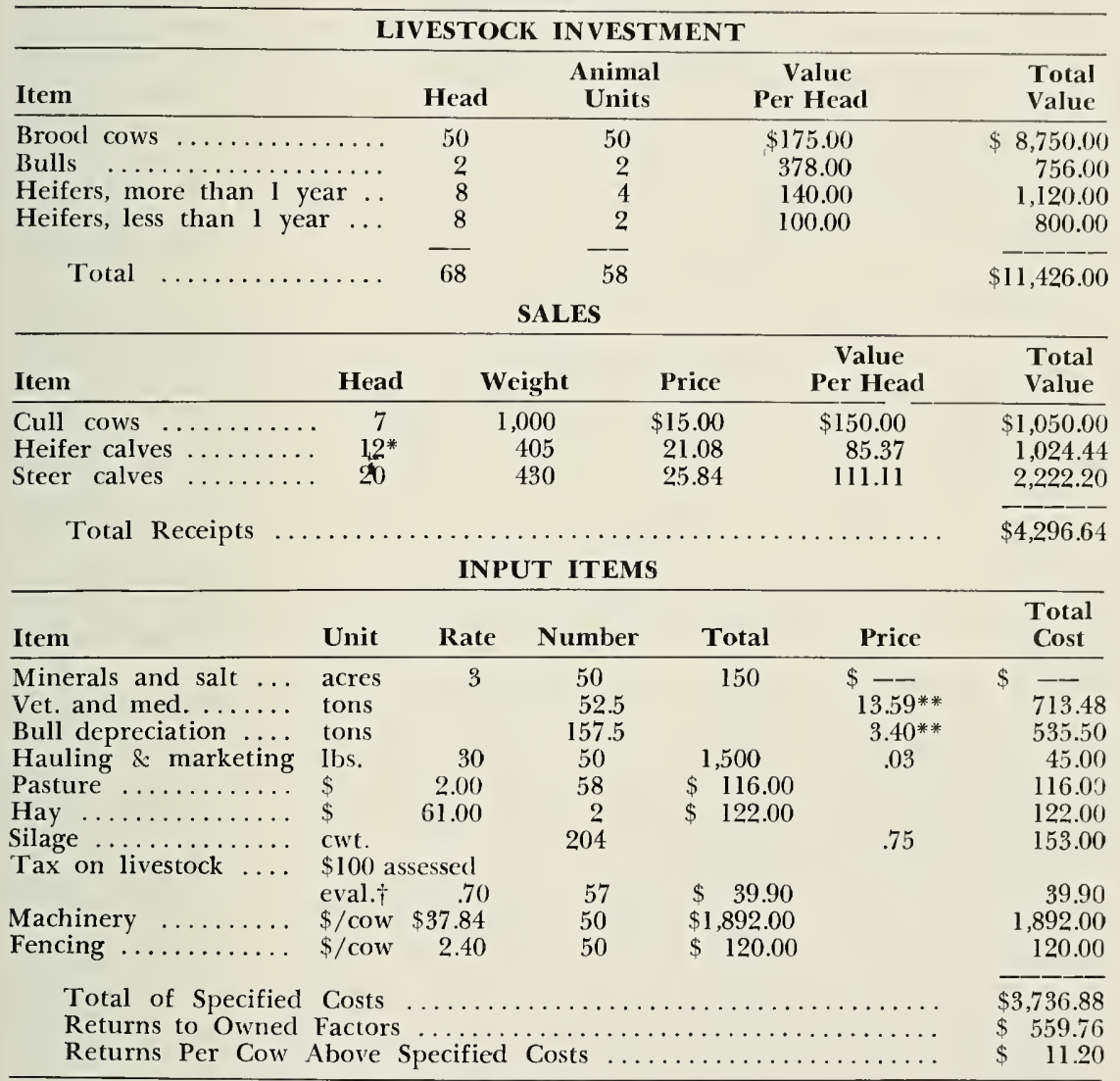

* Assuming eight heifers kept for replacement.

* Includes variable costs of production only.

$\leftarrow$ Assessed evaluation equal to 50 per cent of actual value.

more than for the corresponding 50-cow herd. This reduction is largely due to more efficient use of machinery.

In Table 9.07 computations are based on an 80 per cent calf crop and average selling weights of 420 pounds. Returns per cow above specified costs are $\$ 27.81$. With a 90 per cent calf crop returns above costs are increased to $\$ 37.57$ per cow (Table 9.08 ). With a 90 per cent calf crop and a 470-pound average selling weight of calves, returns above specified costs are $\$ 41.63$ (Table 9.09). 
TABLE 9.05

Estimated Production Requirements and Income for a Beef Herd of 50 Cows; Winter Ration Hay and Silage; Assuming 90 Per Cent Calf Crop; Selling Feeder Calves Averaging 420 Pounds, October 15

\begin{tabular}{|c|c|c|c|c|}
\hline \multicolumn{5}{|c|}{ LIVESTOCK INVESTMENT } \\
\hline Item & Head & $\underset{\text { Units }}{\text { Animal }}$ & $\begin{array}{c}\text { Value } \\
\text { Per Head }\end{array}$ & $\begin{array}{l}\text { Total } \\
\text { Value }\end{array}$ \\
\hline Brood cows & 50 & 50 & $\$ 175.00$ & $\$ 8,750.00$ \\
\hline Bulls $\ldots \ldots \ldots \ldots \ldots$ & 2 & 2 & 378.00 & 756.00 \\
\hline Heifers, more than 1 year & 8 & 4 & 140.00 & $1,120.00$ \\
\hline Heifers, less than 1 year. & 8 & 2 & 100.00 & 800.00 \\
\hline Total $\ldots \ldots \ldots \ldots \ldots$ & 68 & 58 & & $\$ 11,426.00$ \\
\hline
\end{tabular}

SALES

\begin{tabular}{|c|c|c|c|c|c|}
\hline Item & Head & Weight & Price & $\begin{array}{c}\text { Value } \\
\text { Per Head }\end{array}$ & $\begin{array}{l}\text { Total } \\
\text { Value }\end{array}$ \\
\hline Cull cows .. & 7 & $\mathrm{I}, 000$ & $\$ 15.00$ & $\$ 150.00$ & $\$ 1,050.00$ \\
\hline Heifer calves & $14^{*}$ & 405 & 21.08 & 85.37 & $1,195.18$ \\
\hline Steer calves & 23 & 430 & 25.84 & 111.11 & $2,555.53$ \\
\hline
\end{tabular}

INPUT ITEMS

\begin{tabular}{|c|c|c|c|c|c|c|}
\hline Item & Unit & Rate & Number & Total & Price & $\begin{array}{l}\text { Total } \\
\text { Cost }\end{array}$ \\
\hline$\overline{\text { Pasture }}$ & acres & 3 & 50 & 150 & $\$--$ & $\ldots$ \\
\hline Hay $\ldots$ & tons & & 52.5 & 52.5 & $13.59 * *$ & 713.48 \\
\hline Silage $\ldots \ldots \ldots \ldots$ & tons & & 157.5 & & $3.40 * *$ & 535.50 \\
\hline Minerals and salt & lbs. & 30 & 50 & 1,500 & .03 & 45.00 \\
\hline Vet. and med. . & $\$$ & 2.00 & 58 & $\$ 116.00$ & & 116.90 \\
\hline Bull depreciation .... & $\$$ & 61.00 & 2 & $\$ 122.00$ & & 122.00 \\
\hline Hauling \& marketing & cwt. & & 226 & & .75 & 169.50 \\
\hline \multirow[t]{2}{*}{ Tax on livestock .... } & \multicolumn{2}{|c|}{$\$ 100$ assessed } & & & & \\
\hline & eval. $\dagger$ & .70 & 57 & $\$ \quad 39.90$ & & 39.90 \\
\hline Machinery & $\$ /$ co & 37.84 & 50 & $\$ 1,892.00$ & & $1,892.00$ \\
\hline Fencing .. & $\$ /$ cow & 2.40 & 50 & $\$ 120.00$ & & 120.00 \\
\hline Total of Specifie & & & & & & $\$ 3,753.38$ \\
\hline Returns to Owned & & & & & & $\$ 1,047.33$ \\
\hline Returns Per Cow & Above $S$ & pecified & Costs & & & $\$ 20.95$ \\
\hline
\end{tabular}

*Assuming eight heifers kept for replacement.

**Includes variable costs of production only.

$\uparrow$ Assessed evaluation equal to 50 per cent of actual value.

\section{TABLES 9.10, 9.11, AND 9.12}

In Tables 9.10, 9.11, and 9.12, production requirements and income are presented for a 100 -cow herd with $1 / 2$ of the forage requirement being provided from silage and $1 / 2$ from hay (assuming 3 tons of silage equal to 1 ton of hay). With a beef herd as large as 100 head, hay and silage equipment can almost be as economically owned as can hay equipment alone. The additional cost of owning the silage equipment can almost 


\section{TABLE 9.06}

Estimated Production Requirements and Income for a Beef Herd of 50 Cows; Winter Ration of Alfalfa-Mixed Hay and Silage; Assuming 90 Per Cent Calf Crop; Selling Feeder Calves Averaging 470 Pounds, October 15

\begin{tabular}{|c|c|c|c|c|}
\hline \multicolumn{5}{|c|}{ LIVESTOCK INVESTMENT } \\
\hline Item & Head & $\underset{\text { Units }}{\text { Animal }}$ & $\begin{array}{c}\text { Value } \\
\text { Per Head }\end{array}$ & $\begin{array}{l}\text { Total } \\
\text { Value }\end{array}$ \\
\hline Brood cows ... & 50 & 50 & $\$ 175.00$ & $\$ 8,750.00$ \\
\hline Bulls $\quad \ldots \ldots \ldots \ldots \ldots \ldots \ldots$ & 2 & 2 & 378.00 & 756.00 \\
\hline Heifers, more than 1 year .. & 8 & $\overline{4}$ & 140.00 & $1,120.00$ \\
\hline Heifers, less than 1 year ... & 8 & 2 & 100.00 & 800.00 \\
\hline Total & 68 & 58 & & $\$ 11,426.00$ \\
\hline
\end{tabular}

SALES

\begin{tabular}{lccccr}
\hline Item & Head & Weight & Price & $\begin{array}{c}\text { Value } \\
\text { Per Head }\end{array}$ & $\begin{array}{r}\text { Total } \\
\text { Value }\end{array}$ \\
\hline Cull cows $\ldots \ldots \ldots \ldots$ & 7 & 1,000 & $\$ 15.00$ & $\$ 150.00$ & $\$ 1,050.00$ \\
Heifer calves $\ldots \ldots \ldots$ & $14^{*}$ & 455 & 20.08 & 91.36 & $1,279.04$ \\
Steer calves $\ldots \ldots \ldots$ & 23 & 485 & 24.84 & 120.47 & $2,770.81$
\end{tabular}

Total Receipts

$\$ 5,099.85$

INPUT ITEMS

\begin{tabular}{|c|c|c|c|c|c|c|c|}
\hline Item & Unit & Rate & Number & Total & Price & & $\begin{array}{l}\text { Total } \\
\text { Cost }\end{array}$ \\
\hline Pasture & acres & 3 & 50 & 150 & $\$--$ & $\$$ & - - \\
\hline Hay .. & tons & & & 55.5 & $13.59 * *$ & & 754.24 \\
\hline Silage $\ldots \ldots \ldots \ldots$ & tons & & & 166.5 & $3.40 * *$ & & 566.10 \\
\hline Minerals and salt .... & lbs. & 30 & 50 & 1,500 & .03 & & 45.00 \\
\hline Vet. and med. ...... & $\$$ & 2.00 & 58 & $\$ 116.00$ & & & 116.00 \\
\hline Bull depreciation .... & $\$$ & 61.00 & 2 & $\$ 122.00$ & & & 122.00 \\
\hline Hauling \& marketing & cwt. & & & $\$ 245.00$ & .75 & & 183.75 \\
\hline Tax on livestock .... & $\$ 100$ as & sessed & & & & & \\
\hline Machinery & $\begin{array}{l}\text { eval. } \dagger \\
\$ / \text { cow }\end{array}$ & $\begin{array}{r}.70 \\
\$ 37.84\end{array}$ & $\begin{array}{l}57 \\
50\end{array}$ & $\begin{array}{l}\$ 39.90 \\
\$ 189900\end{array}$ & & & $\begin{array}{r}39.90 \\
89200\end{array}$ \\
\hline Fencing .... & $\$ /$ cow & 2.40 & 50 & $\$ 120.00$ & & & 120.00 \\
\hline \multirow{3}{*}{\multicolumn{4}{|c|}{ 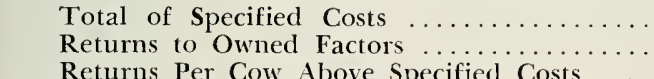 }} & & & & $3,838.99$ \\
\hline & & & & & & & $1,260.86$ \\
\hline & & & & & & & 25.22 \\
\hline
\end{tabular}

*Assuming eight heifers kept for replacement.

**Includes variable costs of production only.

+ Assessed evaluation equal to 50 per cent of actual value.

be offset by the lower cost of production and harvesting silage. The fixed cost of owning both hay and silage equipment exceeds the fixed cost of hay machinery by about $\$ 529$ per year. However, a ton of hay equivalent can be produced and harvested for $\$ 10.20$ (\$3.40 × 3 tons) as corn silage; but as alfalfa-mixed hay the cost is $\$ 19.59$ per ton. or $\$ 3.39$ per ton more. Thus, when 450 or more tons of silage (150 ton hay-equir- 
TABLE 9.07

Estimated Production Requirements and Income for a Beef Herd of 100 Cows, Winter Ration of Alfalfa-Mixed Hay; Assuming 80 Per Cent Calf Crop; Selling Feeder Calves Weighing 420 Pounds, October 15

\begin{tabular}{|c|c|c|c|c|}
\hline \multicolumn{5}{|c|}{ LIVESTOCK INVESTMENT } \\
\hline Item & Head & $\underset{\text { Units }}{\text { Animal }}$ & $\begin{array}{c}\text { Value } \\
\text { Per Head }\end{array}$ & $\begin{array}{l}\text { Total } \\
\text { Value }\end{array}$ \\
\hline Brood cows & 100 & 100 & $\$ 175.00$ & $\$ 17,500.00$ \\
\hline Bulls $\ldots \ldots \ldots \ldots \ldots \ldots \ldots$ & 4 & 4 & 378.00 & $1,512.00$ \\
\hline Heifers, more than 1 year. & 16 & 8 & 140.00 & $2,240.00$ \\
\hline Heifers, less than 1 year.. & 16 & 4 & 100.00 & $1,600.00$ \\
\hline Total & 136 & 116 & & $\$ 22,852.00$ \\
\hline
\end{tabular}

SALES

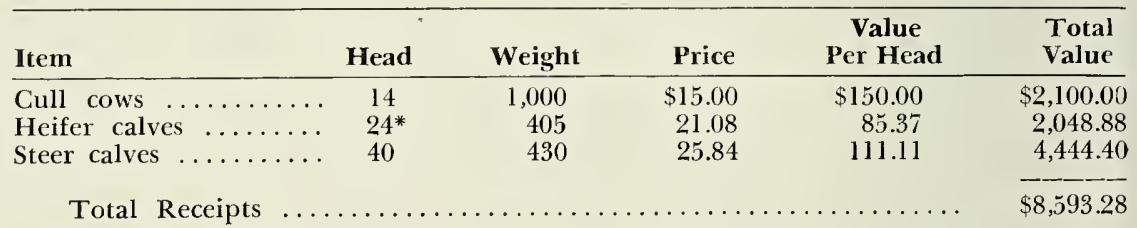

INPUT ITEMS

\begin{tabular}{|c|c|c|c|c|c|c|}
\hline Item & Unit & Rate & Number & Total & Price & $\begin{array}{l}\text { Total } \\
\text { Cost }\end{array}$ \\
\hline Pasture & acres & 3 & 100 & 300 & $\$--$ & $\$--$ \\
\hline Hay......... & tons & & 210 & & $13.59 * *$ & $2,853.90$ \\
\hline Minerals and salt .... & lbs & 30 & 100 & 3,000 & $.03^{* *}$ & 90.00 \\
\hline Vet. and med. ....... & $\$$ & 2.00 & 116 & $\$ 232.00$ & & 232.00 \\
\hline Bull depreciation ... & $\$$ & 61.00 & 4 & $\$ 244.00$ & & 244.00 \\
\hline Hauling \& marketing & cwt. & & 409 & & .75 & 306.75 \\
\hline Tax on livestock .... & $\$ 100$ as & ssessed & & & & 7080 \\
\hline Machinery . & $\$ /$ cow & 17.66 & 100 & $\$ 1,766.00$ & & $\begin{array}{r}79.80 \\
1,766.00\end{array}$ \\
\hline Fencing ...... & $\$ /$ cow & 2.40 & 100 & & & 240.00 \\
\hline $\begin{array}{l}\text { Total of Specified } \\
\text { Returns to Owned }\end{array}$ & Costs & & & & & $\$ 5,812.45$ \\
\hline $\begin{array}{l}\text { Returns to Owned } \\
\text { Returns Per Cow }\end{array}$ & $\begin{array}{l}\text { Factor } \\
\text { Above }\end{array}$ & Specified & Costs & & & $\$ \quad 27.81$ \\
\hline
\end{tabular}

*Assuming eight heifers kept for replacement.

* * Includes variable costs of production only.

+ Assessed evaluation equal to 50 per cent of actual value.

alent) is utilized, the total cost is about as low with silage and hay as with hay alone. If silos are available, the larger the percentage of the forage requirement produced in the form of corn silage, the lower the total cost of producing forage for the 100-cow herd. 
TABLE 9.09

Estimated Production Requirements and Income for a Beef Herd of 100 Cows, Winter Ration of Alfalfa-Mixed Hay; Assuming 90 Per Cent Calf Crop; Selling Feeder Calves Averaging 470 Pounds, October 15

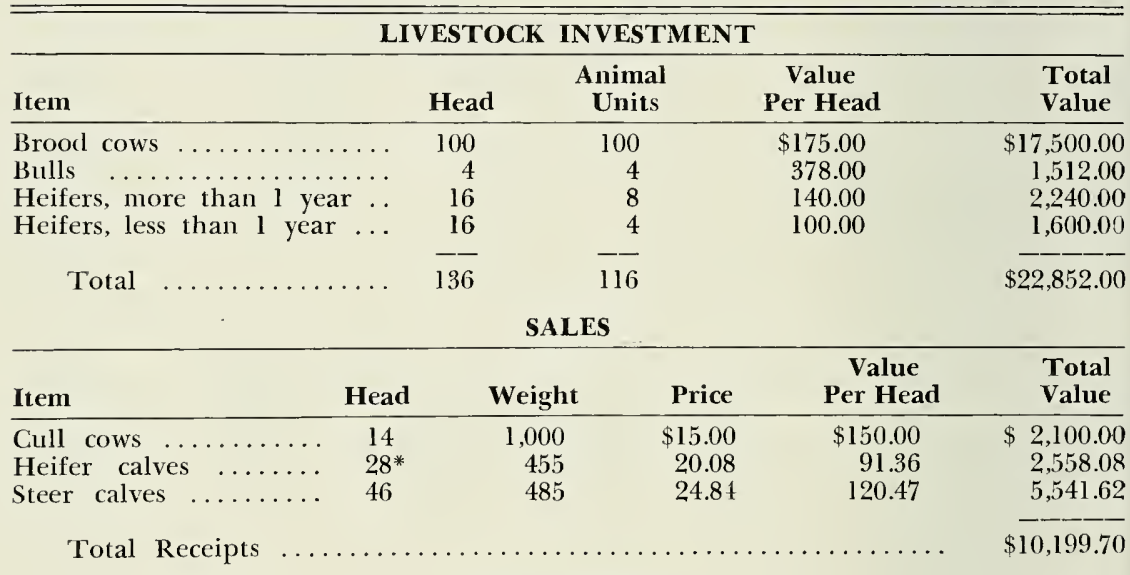

INPUT ITEMS

\begin{tabular}{|c|c|c|c|c|c|c|}
\hline Item & Unit & Rate & Number & Total & Price & $\begin{array}{l}\text { Total } \\
\text { Cost } \\
\end{array}$ \\
\hline Pasture & acres & 3 & 100 & 300 & $\$--$ & $\$--$ \\
\hline Hay $\ldots . . . \ldots$. & tons & & 222 & & $13.59 * *$ & $3,016.98$ \\
\hline Minerals and salt & lbs & 30 & 100 & 3,000 & $.03 * *$ & 90.00 \\
\hline Vet. and merl. ... & $\$$ & 2.00 & 116 & $\$ 232.00$ & & 232.00 \\
\hline Bull depreciation .... & $\$$ & 61.00 & 4 & $\$ 244.00$ & & 244.00 \\
\hline Hauling \& marketing & cwt. & & 490 & & .75 & 367.50 \\
\hline \multirow{2}{*}{ Tax on livestock .... } & $\$ 100$ as & sessed & & & & \\
\hline & eval. $\dagger$ & .70 & 114 & & & 79.80 \\
\hline Machinery & $\$ /$ cow & 17.66 & 100 & & & $1,766.00$ \\
\hline Fencing $\ldots$ & $\$ /$ cow & 2.40 & 100 & & & 240.00 \\
\hline Total of Specified & Costs & & & & & $\$ 6,036.28$ \\
\hline Returns to Owned & I Factor & & & & & $\$ 4,163.42$ \\
\hline Returns Per Cow & Above $\mathrm{S}$ & pecified & Costs & & & $\$ \quad 41.63$ \\
\hline
\end{tabular}

*Assuming eight heifers kept for replacement.

* * Includes variable costs of production only.

† Assessed evaluation equal to 50 per cent of actual value. 
TABLE 9.10

Estimated Production Requirements and Income for a Beef Herd of 100 Cows, Winter Ration Alfalfa-Mixed Hay and Silage; Assuming 80 Per Cent Calf Crop; Selling Feeder Calves Weighing 420 Pounds, October 15

\begin{tabular}{|c|c|c|c|c|}
\hline \multicolumn{5}{|c|}{ LIVESTOCK INVESTMENT } \\
\hline Item & Head & $\underset{\text { Units }}{\text { Animal }}$ & $\begin{array}{c}\text { Value } \\
\text { Per Head }\end{array}$ & $\begin{array}{l}\text { Total } \\
\text { Value }\end{array}$ \\
\hline Brood cows & 100 & 100 & $\$ 175.00$ & $\$ 17,500.00$ \\
\hline Bulls $\quad \ldots \ldots \ldots \ldots \ldots \ldots$ & $\frac{4}{1}$ & 4 & 378.00 & $1,512.00$ \\
\hline Heifers, more than 1 year .. & 16 & 8 & $\mathrm{I} 40.00$ & $2,240.00$ \\
\hline Heifers, less than 1 year ... & 16 & 4 & 100.00 & $1,600.00$ \\
\hline Total & 136 & 116 & & $\$ 22.852 .00$ \\
\hline
\end{tabular}

SALES

\begin{tabular}{|c|c|c|c|c|c|}
\hline Item & Head & Weight & Price & $\begin{array}{c}\text { Value } \\
\text { Per Head }\end{array}$ & $\begin{array}{l}\text { Total } \\
\text { Value }\end{array}$ \\
\hline CuIl cows & 14 & 1,000 & $\$ 15.00$ & $\$ 150.00$ & $\$ 2,100.00$ \\
\hline Heifer calves & $24 *$ & 405 & 21.08 & 85.37 & $2,0.48 .88$ \\
\hline Steer calves & 40 & 430 & 25.84 & 111.11 & $4,444.40$ \\
\hline
\end{tabular}

INPUT ITEMS

\begin{tabular}{|c|c|c|c|c|c|c|}
\hline Item & Unit & Rate & Number & Total & Price & $\begin{array}{l}\text { Total } \\
\text { Cost }\end{array}$ \\
\hline Pasture & acres & 3 & 100 & 300 & $\$--$ & - - \\
\hline Hay .. & tons & & 105 & & $13.59 * *$ & $1,426.95$ \\
\hline Silage $\ldots \ldots \ldots$ & tons & & 315 & & $3.40 * *$ & $1,071.00$ \\
\hline Minerals and salt .... & Ibs & 30 & 100 & 3,000 & $.03^{\prime}$ & 90.00 \\
\hline Vet. and med. ...... & $\$$ & 2.00 & 116 & $\$ 232.00$ & & 232.00 \\
\hline Bull depreciation .... & $\$$ & 61.00 & 4 & $\$ 244.00$ & & 244.00 \\
\hline Hauling \& marketing & cwt. & & 409 & & .75 & 306.75 \\
\hline Tax on livestock .... & $\$ 100$ as & $\operatorname{sessed}$ & & & & \\
\hline & eval. $\dagger$ & .70 & 114 & & & 79.80 \\
\hline Machinery & $\$ /$ cow & 22.95 & 100 & $\$ 2,295.00$ & & 2.295 .00 \\
\hline Fencing ... & $\$ /$ cow & 2.40 & 100 & & & 240.00 \\
\hline \multicolumn{6}{|c|}{ Total of Specified Costs } & $\$ 5,985.50$ \\
\hline \multirow{2}{*}{\multicolumn{6}{|c|}{$\begin{array}{l}\text { Returns to Owned Factors } \\
\text { Returns Per Cow Above Specified }\end{array}$}} & $\$ 2,607.78$ \\
\hline & & & & & & $\$ 26.08$ \\
\hline
\end{tabular}

* Assuming eight heifers kept for replacement.

* Includes variable costs of production only.

tAssessed evaluation equal to 50 per cent of actual value. 
TABLE 9.11

Estimated Production Requirements and Income for a Beef Herd of 100 Cows, Winter Ration Alfalfa-Mixed Hay and Silage; Assuming 90 Per Cent Calf Crop; Selling Feeder Calves Weighing 420 Pounds, October 15

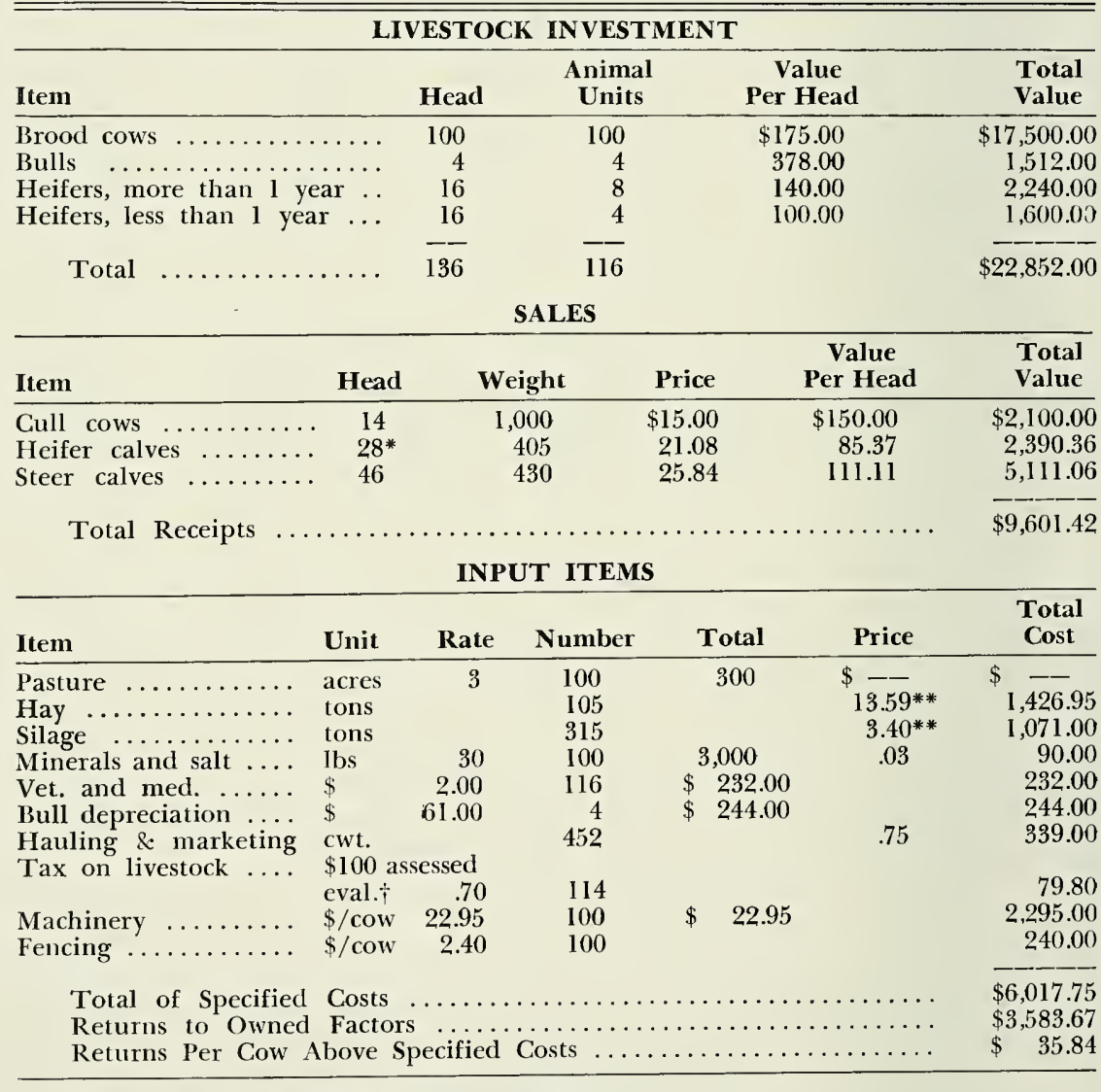

*Assuming eight heifers kept for replacement.

**Includes variable costs of production only.

+ Assessed evaluation equal to 50 per cent of actual value. 


\section{Summary and Conclusions}

The costs of producing feeder calves and the return to owned factors of production-land, buildings, livestock investment, labor, and management-vary greatly depending upon the size of the herd and the effectiveness of management. The results of good management are reflected in the number, quality, and weight of calves going to market, and in the productivity of the cropland and the resulting cost per ton of producing forages.

Machinery costs are a critical factor in determining the profitability of a beef herd. The minimum investment in machinery to produce the forage for a beef herd dictates that the minimum number of cows in the heard be 50 or more to reduce the fixed costs per cow below expected returns.

Returns to owned factors of production from a 50-cow herd range from $\$ 560$ to $\$ 1,600$ (\$11.20 to $\$ 32$ per head) for the systems considered. Returns from comparable systems ranged from $\$ 2,608$ to $\$ 4,163$ from a 100-cow herd.

To obtain an average annual return of $\$ 4,000$ or greater to the factors assumed to be owned, a beef herd of approximately 100 cows, a calf crop of 90 per cent, an average 470-pound selling weight for calves and high crop yields are required. If the producer does not own the above specified factors of production, interest payments for borrowed capital will reduce the income available for family living.

\section{BIBLIOGRAPHY}

Agricultural Engineers' Yearbook, 1962, 1964. "Farm Machinery Costs and Use." pp. 230-235, American Society of Agricultural Engineers, St. Joseph, Michigan.

Barr, A. L., et al. 1960. Beef Cattle Systems and Range Improvement Alternatives: Estimated Production, Income and Costs, Oklahoma State University Processed Series P-358. Oklahoma State University, Stillwater.

Barr, A. L., et al. 1964. Sheep Production-Costs and Returns in West Virginia, W. Va. Univ. Agri. Exp. Sta. Bull. 495. WVest Virginia University, Morgantown.

Field Workers' Blue Book, Livestock Program, I960-1965. "Summary of W'est Virginia Demonstrational Feeder Calf Sales." Cooperative Extension Service, West Virginia University, Morgantown.

"Livestock and Poultry Inventory, January 1," U.S.D.A. SRS, Crop Reporting Board, Washington, D.C., 1962, 1963, 1964, 1965.

West Virginia Agricultural Statistics, 1964. West Virginia Department of Agriculture, Charleston, West Virginia, C. R. Bull., No. 6. 

